\title{
First paleomagnetic results of mid- to late Holocene sediments from Lake Issyk-Kul (Kyrgyzstan): Implications for paleosecular variation in central Asia
}

\author{
Miriam Gómez-Paccard \\ Institute of Earth Sciences Jaume Almera, CSIC, Lluis Solé i Sabaris s/n, E-08028 Barcelona, Spain \\ (mgomezpaccard@ictja.csic.es)
}

\section{Juan C. Larrasoaña}

Unidad de Zaragoza, Instituto Geológico y Minero de España, Manuel Lasala 44, 9B, E-50006

Zaragoza,Spain (jc.larra@igme.es)

\section{Santiago Giralt}

Institute of Earth Sciences Jaume Almera, CSIC, Lluís Solé i Sabaris s/n, E-08028 Barcelona, Spain (sgiralt@ictja.csic.es)

\section{Andrew P. Roberts \\ Research School of Earth Sciences, Australian National University, Canberra, ACT 0200, Australia (andrew.roberts@anu.edu.au)}

[1] We present new paleomagnetic and rock magnetic data from mid and late Holocene sediments recovered in two gravity cores (C087 and C142a) from Lake Issyk-Kul (central Asia), for which independent radiocarbon-based age models are available. Our results indicate that sediments from core C087 are characterized by fine (pseudo single domain) magnetite grains and are reliable recorders of Holocene geomagnetic paleosecular variation (PSV) in central Asia, which is a region with poor data coverage. Similarity is found between the core C087 PSV record, which spans the last 5700 years, and the Lake Baikal PSV record, which is the only published Holocene central Asian PSV record of comparable length with an independent radiocarbon-based chronology. Our new results represent a step forward in constructing a reference PSV curve for central Asia that can be used to date sedimentary sequences. These results can also be used to improve the reliability and accuracy of global geomagnetic field models. We have not been able to disentangle past environmental changes in the Lake Issyk-Kul region based on rock magnetic properties, probably because the magnetite and hematite in the studied sediments have a mixed (fluvial and eolian) terrigenous origin.

Components: 8600 words, 7 figures, 1 table.

Keywords: Holocene; central Asia; lacustrine sediments; paleomagnetism; rock magnetism; secular variation.

Index Terms: 1522 Geomagnetism and Paleomagnetism: Paleomagnetic secular variation; 1532 Geomagnetism and Paleomagnetism: Reference fields: regional, global; 1540 Geomagnetism and Paleomagnetism: Rock and mineral magnetism.

Received 19 December 2011; Revised 15 February 2012; Accepted 20 February 2012; Published 23 March 2012.

Gómez-Paccard, M., J. C. Larrasoaña, S. Giralt, and A. P. Roberts (2012), First paleomagnetic results of mid- to late Holocene sediments from Lake Issyk-Kul (Kyrgyzstan): Implications for paleosecular variation in central Asia, Geochem. Geophys. Geosyst., 13, Q03019, doi:10.1029/2011GC004015. 


\section{Introduction}

[2] Documentation of geomagnetic field variations provides important information on the operation of the geodynamo and on links between solar activity and Earth's climate via improved interpretations of cosmogenic isotopes [Muscheler et al., 2005]. Geomagnetic field changes can also have important applications in geochronologic studies of Quaternary sediments [e.g., Snowball et al., 2007; LiséPronovost et al., 2009; Barletta et al., 2010] and for testing the controversial hypothesized links between Earth's magnetic field and climate [e.g., Wollin et al., 1978; Gallet et al., 2005; Snowball and Muscheler, 2007; Courtillot et al., 2007; Bard and Delaygue, 2008; Gómez-Paccard et al., 2008]. Beyond instrumental records available for the last 400 years, past geomagnetic field variations are best obtained from fired archeological materials and volcanic rocks. The magnetic signals recorded by these materials are thermoremanent magnetizations [Néel, 1955], which provide accurate paleomagnetic directions and enable determination of absolute paleointensities. Well-dated sedimentary records can also give reliable information on changes in the direction and relative intensity of the geomagnetic field [e.g., Stockhausen, 1998; Ali et al., 1999; Frank et al., 2002; Vigliotti, 2006; Irurzun et al., 2006, 2008; Snowball et al., 2007]. Rapidly deposited sediments are often targeted for geomagnetic field studies due to the possibility of obtaining information on shorter period variations than can be obtained from archeomagnetic and volcanic data throughout the Holocene.

[3] Archeomagnetic, volcanic and sedimentary data can be used to construct regional curves of both the direction and intensity of the geomagnetic field [e.g., Gómez-Paccard et al., 2006, 2008; Snowball et al., 2007] or to compute regional or global geomagnetic field models [e.g., Pavón-Carrasco et al., 2009; Korte and Constable, 2005; Korte et al., 2009] that can help to describe the temporal and spatial behavior of the geomagnetic field on centennial timescales. The accuracy and reliability of such curves and models relies on the quality, quantity and the spatial and temporal distribution of the paleomagnetic data used for their construction. A crucial issue for improving the reliability of geomagnetic field models is the fidelity of the data used for their construction. Thus, chronological uncertainties associated with the input data affect the temporal resolution of the models and strongly influence the structure of the modeled magnetic field variations [Korte and Constable, 2005]. One of the regions in the world with strikingly poor data coverage is central Asia, where only three sedimentary paleosecular variation (PSV) records are available for the last six millennia from a region that covers more than $24 \times 10^{6} \mathrm{~km}^{2}$ (about $5 \%$ of the Earth's surface) and extends from about 6 to $43.5^{\circ} \mathrm{N}$ and 54 to $107^{\circ} \mathrm{E}$ (Figure 1a). The Lake Aslikul record spans from $2450 \mathrm{yr}$ BC to $1900 \mathrm{yr}$ AD [Nurgaliev et al., 1996] with high temporal resolution $(\sim 10$ yr). The Aral Sea PSV record also has high resolution ( $\sim 25 \mathrm{yr})$, but spans (only) 525 to 1675 yr [Nourgaliev et al., 2003]. The Lake Baikal record [Peck et al., 1996] covers from $1575 \mathrm{yr} \mathrm{AD}$ to beyond the Holocene with much lower resolution $(\sim 150 \mathrm{yr})$. Variable geomagnetic field changes are expected over this vast region. Therefore, new PSV data from this region are important for constructing geomagnetic field models.

[4] We present a new paleomagnetic and rockmagnetic study of mid to late Holocene sediments from Lake Issyk-Kul (Figure 1), which were recovered in two gravity cores $(\mathrm{C} 142 \mathrm{a}$ and $\mathrm{C} 087)$ for which independent radiocarbon-based age models are available [Larrasoaña et al., 2011]. Our results contribute to improving PSV data coverage in a virtually unexplored region and can be used to test and improve geomagnetic field models. Rock magnetic data are used to assess the reliability of the PSV record obtained and to discuss the significance of environmental variations in the studied sediments for the last six millennia.

\section{Geological Setting and Methods}

[5] Lake Issyk-Kul (182 km long, $60 \mathrm{~km}$ wide, $668 \mathrm{~m}$ deep, $1607 \mathrm{~m}$ a.s.1.) is a large, endorheic and slightly saline lake (about $6 \mathrm{~g} / \mathrm{l}$ of total dissolved solids) that is located in one of the largest Neogene intermontane basins of the Tien Shan range (Figure 1a). The lake is located between the Kungey (to the north) and Terzkey (to the south) ranges (Figure $1 \mathrm{~b}$ ), which reach altitudes of up to nearly $6000 \mathrm{~m}$ a.s.l. and are mainly composed of PreCambrian and Paleozoic crystalline rocks [Torizin et al., 2009]. The lake has a relatively small catchment (250 km long and $100 \mathrm{~km}$ wide) compared with the size of the lake [Zabirov and Korotaev, 1978]. There are about 100 streams and rivers that feed the lake. The two largest rivers (Jergueland and Tyup) are located to the east of the lake. They are predominantly fed by meltwater from glaciers and snow from the Terzkey Ranges. One of the most noticeable features of the lake is the annual lake level oscillation of about $40 \mathrm{~cm}$ 
a)

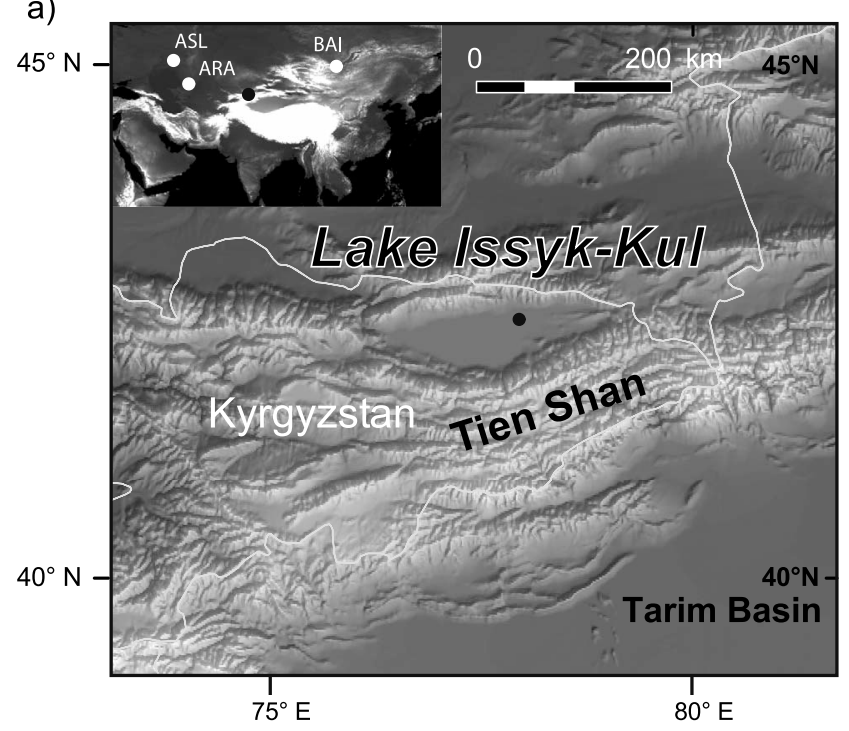

d)

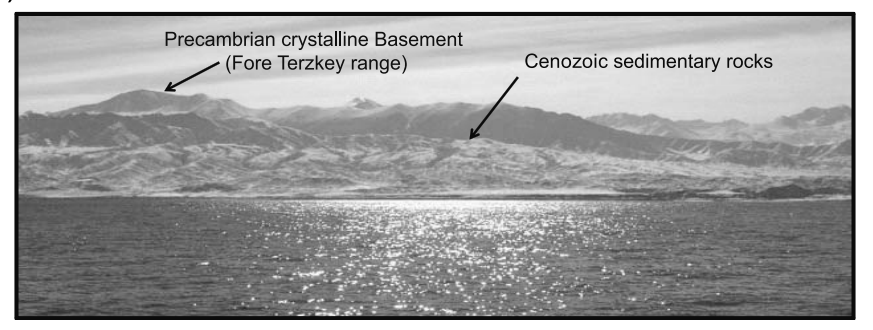

b)

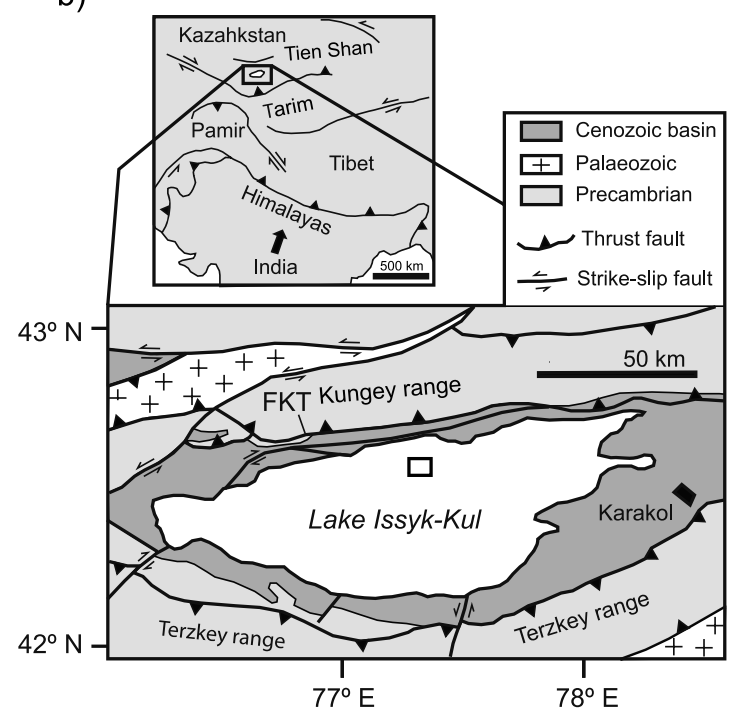

c)

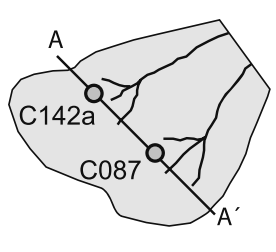

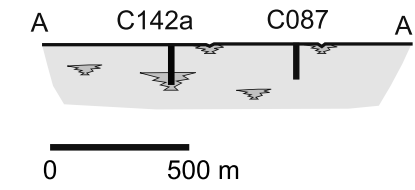

Figure 1. (a) Location of Lake Issyk-Kul, and of other lacustrine records mentioned (ASL: Lake Aslikul; BAI: Lake Baikal; ARA: Aral Sea). (b) Geological sketch map of the Lake Issyk-Kul basin and surrounding mountain ranges in the context of India-Asia collision (FKT: Fore Kungey Thrust). The black dot (box) in Figure 1a (Figure 1b) denotes the location of the studied cores. (c) Sketch of the location of the studied cores (with schematic geologic cross-section) within a lobe of the deltaic system that drains the northern shore of Lake Issyk-Kul [after Larrasoaña et al., 2011 ]. (d) Southwestern shore of Lake Issyk-Kul viewed from the center of the lake.

associated with the main precipitation peak and ice and snow melting (spring and summer) and ice and snow accumulation (autumn and winter) in the ice caps of the surrounding mountains. The sedimentary infill of Lake Issyk-Kul consists of a mixture of lacustrine carbonates and riverine and eolian terrigenous sediments that record Miocene through Holocene deposition [De Batist et al., 2002; Giralt et al., 2004]. In August 2000, two azimuthally unoriented continuous gravity cores, $\mathrm{C} 142 \mathrm{a}\left(42^{\circ} 34^{\prime}\right.$ $\left.31.2^{\prime \prime} \mathrm{N}, 77^{\circ} 20^{\prime} 03.0^{\prime \prime} \mathrm{E}\right)$ and $\mathrm{C} 087\left(42^{\circ} 34^{\prime} 5.22^{\prime \prime} \mathrm{N}\right.$, $77^{\circ} 20^{\prime} 10.44^{\prime \prime} \mathrm{E}$ ), were retrieved on board the $\mathrm{R} / \mathrm{V}$ Moltur from the central northern shore of the lake at water depths of 150 and $312 \mathrm{~m}$, respectively (Figure 1). Core C142a comprises a 150-cm-thick sequence of Late Holocene clays, silts and sandy silts that accumulated in a distal lobe of the deltaic system that drains into the lake along a NE-SW direction [De Batist et al., 2002; Larrasoaña et al.,
2011] (Figures $1 \mathrm{~b}$ and 1c). Core C087 comprises $132 \mathrm{~cm}$ of clays and silty clays that are equivalent to those in the uppermost $94 \mathrm{~cm}$ of core C142a. The lack of coarser-grained sediments at the base of core C087 might be explained by the discontinuous nature of deltaic tributary systems (Figure 1c).

[6] Paleomagnetic samples were obtained by pushing plastic boxes $(2 \times 2 \times 2 \mathrm{~cm})$ continuously into the working half of cores C142a and C087. Paleomagnetic analyses were performed at the paleomagnetic laboratory of the Institute of Earth Sciences Jaume Almera (UB-CSIC) in Barcelona. They involved measurement of the low-field magnetic susceptibility $(\chi)$ and progressive alternating field (AF) demagnetization of the natural remanent magnetization (NRM) of all samples. Stepwise $\mathrm{AF}$ demagnetization experiments were conducted 
at 5-10 $\mathrm{mT}$ steps and up to a maximum field of 80 $100 \mathrm{mT}$. Stable characteristic remanent magnetization (ChRM) directions were identified through visual inspection of orthogonal demagnetization plots [Zijderveld, 1967], and were calculated by fitting linear trends in the demagnetization plots using principal component analysis [Kirschvink, 1980]. Additional rock magnetic properties that were measured include the anhysteretic remanent magnetization (ARM) and two isothermal remanent magnetizations that were imparted at $0.1 \mathrm{~T}\left(\mathrm{IRM}_{0.1 \mathrm{~T}}\right)$ and $1.2 \mathrm{~T}\left(\mathrm{IRM}_{1.2} \mathrm{~T}\right)$. $\chi$ was measured with a Kappabridge KLY-2 (Geofyzica Brno) susceptibility bridge using a field of $0.1 \mathrm{mT}$ at a frequency of $470 \mathrm{~Hz}$. AF demagnetization and ARM experiments were conducted using a D-Tech 2000 (ASC Scientific) AF demagnetizer. The ARM was applied along the $\mathrm{Z}$ axis of the samples with a dc bias field of $0.05 \mathrm{mT}$ parallel to a peak AF of $100 \mathrm{mT}$. IRM $\mathrm{IR.1}_{\mathrm{T}}$ and $\mathrm{IRM}_{1.2} \mathrm{~T}$ were imparted using an IM10-30 (ASC Scientific) pulse magnetizer. Magnetizations were measured using a SRM755R (2G Enterprises) threeaxis cryogenic superconducting rock magnetometer.

[7] We used different magnetic properties and interparametric ratios to determine down-core variations in the type, concentration, and grain size of magnetic minerals. Magnetic susceptibility $(\chi)$ has been used as a first-order indicator of the concentration of magnetic (sensu lato) minerals. We have calculated the forward S-ratio (or S'-ratio [see Kruiver and Passier, 2001]), which is defined as $\mathrm{IRM}_{0.1 \mathrm{~T}} / \mathrm{IRM}_{1.2} \mathrm{~T}$ and is equivalent to the S-ratio of Bloemendal et al. [1992]. This S-ratio has been used to indicate the relative concentration of low versus high coercivity minerals. ARM has been used as a proxy for the concentration of low coercivity minerals [e.g., Evans and Heller, 2003]. $\mathrm{IRM}_{1.2 \mathrm{~T}}-\mathrm{IRM}_{0.1 \mathrm{~T}}$, which is equivalent to the "hard" IRM of Bloemendal et al. [1992] (hereafter referred to as HIRM), has been used as a proxy for the concentration of high coercivity minerals. Finally, the $\mathrm{IRM}_{1.2 \mathrm{~T}} / \chi$ ratio has been used to make inferences about the dominant magnetic minerals in a sedimentary sequence [e.g., Peters and Dekkers, 2003] and about relative variations in magnetic mineral grain size, provided that a single magnetic mineral is dominant [Thompson and Oldfield, 1986; Verosub and Roberts, 1995; Evans and Heller, 2003]. Hysteresis measurements for samples from different depths within each core were made using a Princeton Measurements Corporation vibrating sample magnetometer at the Kochi Core Center (Japan) and at the Institute for Rock Magnetism (Minneapolis, USA) to establish the domain state of the magnetic minerals [Day et al., 1977; Dunlop, 2002].

[8] Auxiliary geochemical data include the iron (Fe) and total organic carbon (TOC) contents for core $\mathrm{C} 142 \mathrm{a}$. The Fe content was measured every $0.3 \mathrm{~mm}$ with an ITRAX XRF core scanner at the University of Vigo. A mean value every $2 \mathrm{~cm}$ was calculated using a running average. TOC was measured every centimeter using a UIC model $5011 \mathrm{CO}_{2}$ Coulometer at the Technical Services of the University of Barcelona. All magnetic and geochemical properties are reported in terms of the dry weight of the samples.

\section{Stratigraphy, Sedimentology, and Age Models for the Studied Sediments}

[9] Cores C142a and C087 consist of laminated clays, silts and silty-clays that are arranged into two main lithologic units (Figure 2). The upper unit includes the uppermost $18 \mathrm{~cm}$ and $13 \mathrm{~cm}$ of cores C142a and C087, respectively, and is mainly composed of dark and massive silty-clays. The lower unit extends to the bottom of both cores and is made up of alternating millimeter- to centimeterscale laminae that consist of light and dark gray clays. Sediments in core C142a have a slightly coarser texture in the lowermost $56 \mathrm{~cm}$. Lightcolored laminae are mainly composed of a fine mixture of massive micritic carbonate with other terrigenous minerals such as quartz and phyllosilicates and frequent fragments and whole shells of ostracods and diatoms. Dark-colored lamina consist of massive micritic carbonate with large fragments of partially pyritized plant remains and charcoal, as well as patchy black sulfide-and/or manganeserich accumulations. Millimeter-scale alternations of these laminae appear to be associated with annual water level oscillations, which are driven by the spring melting of surrounding mountain ice caps and accumulation of ice and snow in autumn. On the other hand, centimeter-scale alternations of laminae seem to be related to early diagenetic conditions linked to degradation of organic matter (see Giralt et al. [2002] for further details).

[10] Based on available sedimentologic data, the studied sediments can be interpreted as distal prodeltaic sediments that accumulated on the lake shelf. These sediments are mainly characterized by endogenic carbonates and variable contributions from both riverine (from the Jergueland and Tyup rivers) and eolian (from the Taklamakan Desert in 
a) Core C142a

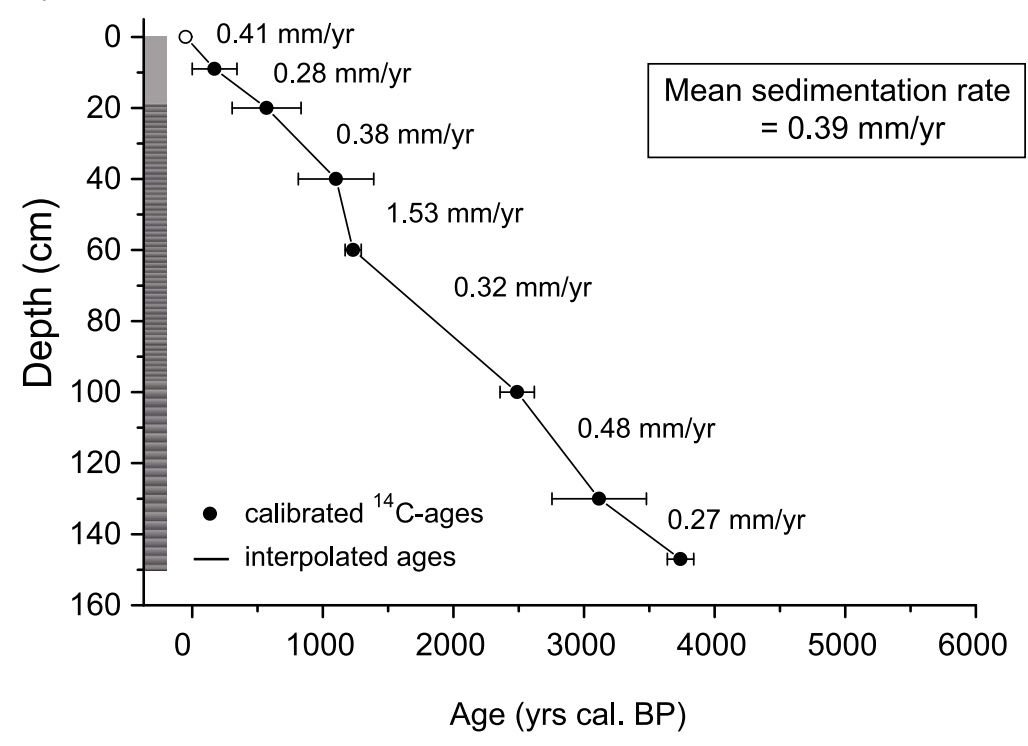

b) Core $\mathrm{C} 087$

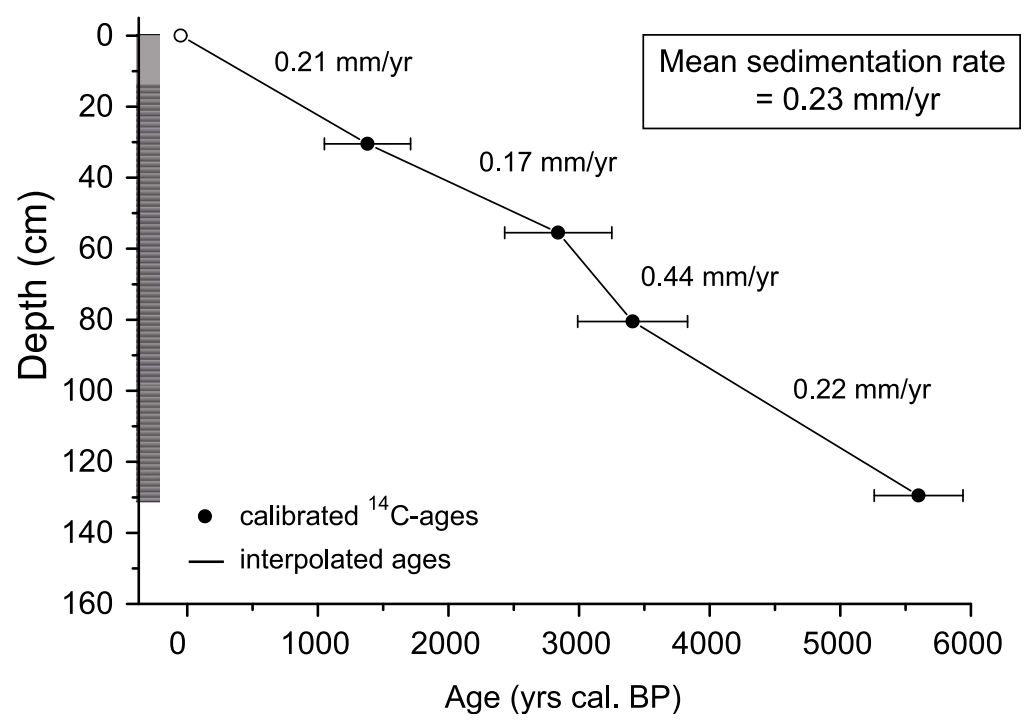

c) Core $\mathrm{C} 142 \mathrm{a}$

d) Core C087

Figure 2. Age models for cores (a) C142a and (b) C087 (see Larrasoaña et al. [2011] for details). The age models are based on AMS radiocarbon datings of pollen-enriched samples (black dots). Lithostratigraphic columns of the studied Holocene sediments from Lake Issyk-Kul, cores (c) C142a and (d) C087. The sedimentation rates derived from the age models are indicated in Figures $2 \mathrm{a}$ and $2 \mathrm{~b}$.

the Tarim basin and other sources) terrigenous material [De Batist et al., 2002; Giralt et al., 2004].

[11] Establishment of an independent chronological framework is crucial to obtain a reliable PSV record. Age models for the studied cores are based on AMS radiocarbon dating of seven and four pollen-enriched samples distributed throughout cores C142a and C087, respectively [Larrasoaña et al., 2011], as no other suitable material for radiocarbon dating was found. The age model of core $\mathrm{C} 142 \mathrm{a}$ was developed after correcting some of the samples for a mean reservoir effect of $1182 \pm$ $135{ }^{14} \mathrm{C}$ yr BP (see Larrasoaña et al. [2011] for a detailed explanation). The same reservoir effect was applied to the four samples from core C087. The constructed age models indicate that the sedimentary records extend back to $1850 \mathrm{yr} \mathrm{BC}$ 
(core C142a) and 3700 yr BC (core C087), respectively. The resulting mean sedimentation rates $(0.39 \mathrm{~mm} / \mathrm{yr}$ and $0.23 \mathrm{~mm} / \mathrm{yr}$ for cores C142a and C087, respectively) (Figure 2) are of the same order as sedimentation rates estimated for other cores from Lake Issyk-Kul [Giralt et al., 2004; Ricketts et al., 2001]. An attempt to AMS ${ }^{14} \mathrm{C}$ date the top of core C087 was unsuccessful given the anomalous age of the core top sample. Nevertheless, occurrence of the same uppermost lithological unit in the two studied cores, which have roughly the same thicknesses as those found in previous cores that have been dated using ${ }^{210} \mathrm{~Pb}$ [Giralt et al., 2004], suggests that the sediment-water interface was recovered in cores C142a and C087. This is supported by extrapolating linear accumulation rates upward from the uppermost radiocarbon date of each core.

[12] The resulting age models indicate that the sampling resolution in cores $\mathrm{C} 142 \mathrm{a}$ and $\mathrm{C} 087$ is about 60 and 100 years, respectively. Although this resolution is lower than typical resolutions attained by studying fired archeological materials (where several well-dated structures can be studied per century), it is similar to that of most lake sediment PSV records (mean resolution of about 100 years) used to construct the new generation of global geomagnetic field models [Donadini et al., 2009; Korte et al., 2009].

\section{Results}

\subsection{Rock Magnetism}

[13] The low-field magnetic susceptibility of core C142a sediments has roughly constant values of about $0.3 * 10^{-6} \mathrm{~m}^{3} / \mathrm{kg}$ down to a depth of $\sim 100 \mathrm{~cm}$, and increases considerably below that depth until reaching a maximum value of $1.2 * 10^{-6} \mathrm{~m}^{3} / \mathrm{kg}$ (Figure 3a). Magnetic susceptibility values for core C087 are roughly constant throughout the core, with a mean value of $0.2 * 10^{-6} \mathrm{~m}^{3} / \mathrm{kg}$ (Figure $3 \mathrm{~b}$ ) that is similar to the mean susceptibility value for the uppermost $100 \mathrm{~cm}$ of core C142a.

[14] S-ratios oscillate around 0.75 throughout most of both cores, which indicate the presence of both low- and high-coercivity magnetic phases. The $\mathrm{IRM}_{1.2} \mathrm{~T} / \chi$ ratio has relatively constant values of around 6 and $13 \mathrm{kA} / \mathrm{m}$ throughout cores C142a and C087, respectively (Figure 3). These values are consistent with magnetite as the main lowcoercivity mineral [Peters and Dekkers, 2003] and point to the absence of the (likely authigenic) magnetic iron sulfides greigite or pyrrhotite [e.g., Larrasoaña et al., 2007] despite evidence for the presence of pyrite. The slightly lower $\operatorname{IRM}_{1.2} \mathrm{~T} / \chi$ ratios for core $\mathrm{C} 142 \mathrm{a}$ suggest coarser magnetite grain sizes compared to core C087 [Peters and Dekkers, 2003]. This is further demonstrated by hysteresis data (Figures $4 \mathrm{a}$ and $4 \mathrm{~b}$ ), which indicate that cores $\mathrm{C} 087$ and $\mathrm{C} 142 \mathrm{a}$ are dominated by a lowcoercivity mineral that spans the PSD and MDcoarse PSD grain size ranges, respectively. Good correlation between hysteresis parameters and $\mathrm{IRM}_{1.2 \mathrm{~T}} / \chi$ (Figures $4 \mathrm{c}$ and $4 \mathrm{~d}$ ) validates the use of $\mathrm{IRM}_{1.2} \mathrm{~T} / \chi$ as a proxy for magnetite grain size throughout the studied cores. Back-field demagnetization data (e.g., Figure 4a, inset) indicate a variable contribution from a high-coercivity mineral, which in the absence of magnetic iron sulfides is interpreted as hematite. The coexistence of this mineral with magnetite is entirely consistent with the S-ratios of the studied sediments [Frank and Nowaczyk, 2008].

[15] ARM values of around 20 to $30 * 10^{-6} \mathrm{Am}^{2} / \mathrm{kg}$ are found throughout most of core $\mathrm{C} 087$ and parts of core C142a, but ARM values exceed $50 * 10^{-6} \mathrm{Am}^{2} / \mathrm{kg}$ in the lowermost $50 \mathrm{~cm}$ of core $142 \mathrm{a}$, in its uppermost $10 \mathrm{~cm}$, and at around $60 \mathrm{~cm}$ deep (Figure 3a). HIRM oscillates around $\sim 5$ to $\sim 8^{*} 10^{-4} \mathrm{Am}^{2} / \mathrm{kg}$ in the upper and lower parts of both cores, respectively. Inspection of depth variations of magnetic properties (e.g., $\chi$, ARM, HIRM, $\left.\mathrm{IRM}_{1.2 \mathrm{~T}} / \chi\right)$ in the studied cores does not reveal a common pattern (Figure 3). Low TOC values $(<1.4 \%)$ and low Fe contents that undergo minor variations throughout core $\mathrm{C} 142 \mathrm{a}$, with no evidence of sharp shifts (Figure 3a), and preservation of magnetite and hematite indicate relatively little diagenetic modification of the magnetic minerals throughout the studied cores.

\subsection{Paleomagnetism}

[16] Progressive AF demagnetization of the NRM indicates the presence of a small viscous component in all samples that always unblocks below 15$20 \mathrm{mT}$ (Figure 5). Above this field and up to $80-100 \mathrm{mT}$, a stable magnetization that is directed toward the origin of the demagnetization plots is identified in all samples except for the two uppermost samples from core C087, which were likely affected by coring disturbances. No evidence for a gyroremanence has been detected in any of the studied samples, which further suggests the lack of magnetic iron sulfides in the studied sediments 
a) Core $\mathrm{C} 142 \mathrm{a}$
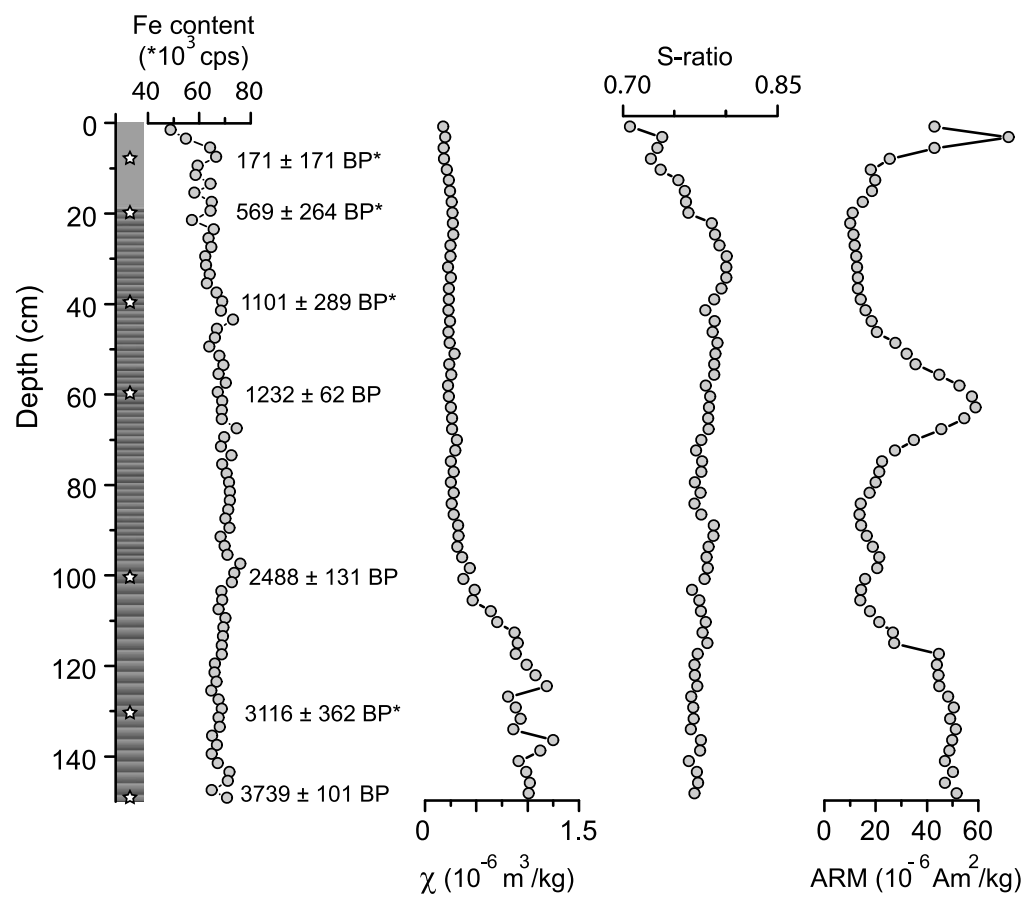

b) Core $\mathrm{C} 087$
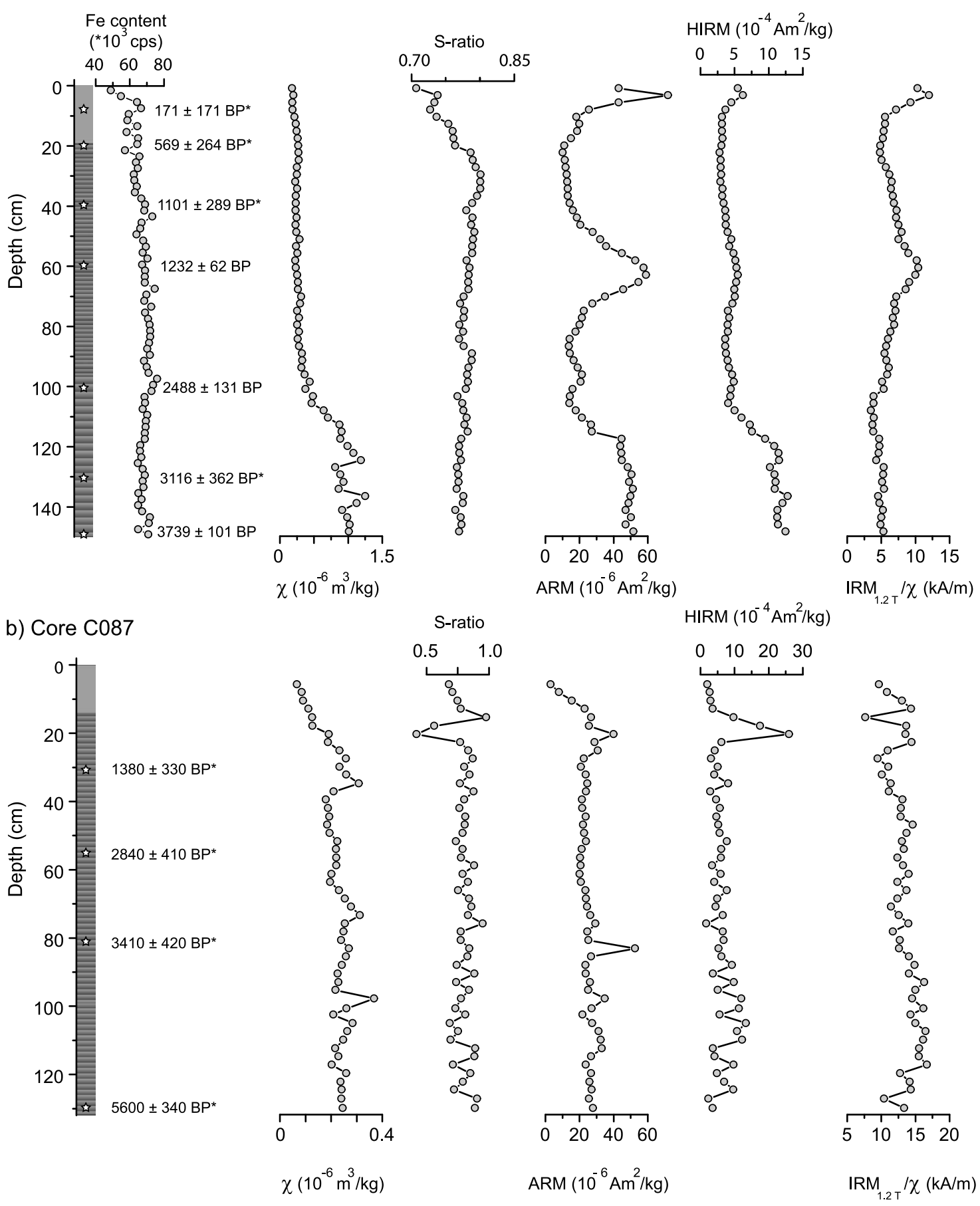

Figure 3. Depth variations of $\mathrm{Fe}$ content (Fe, in counts per second from whole-core XRF measurements), low-field magnetic susceptibility $(\chi)$, S-ratio, ARM, HIRM, and IRM $\mathrm{I}_{1.2} \mathrm{~T} / \chi$ for cores (a) C142a and (b) C087. Positions of AMS radiocarbon dates used to construct the age models are indicated (asterisk denotes ages corrected for a reservoir effect; see Larrasoaña et al. [2011] for details). 
a)

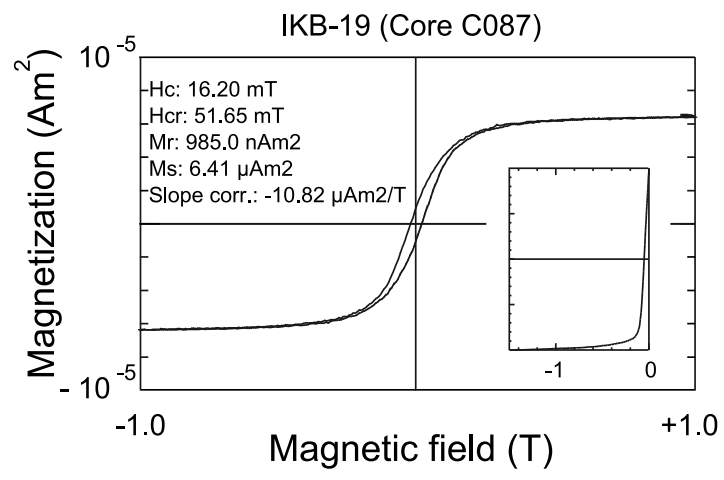

c)

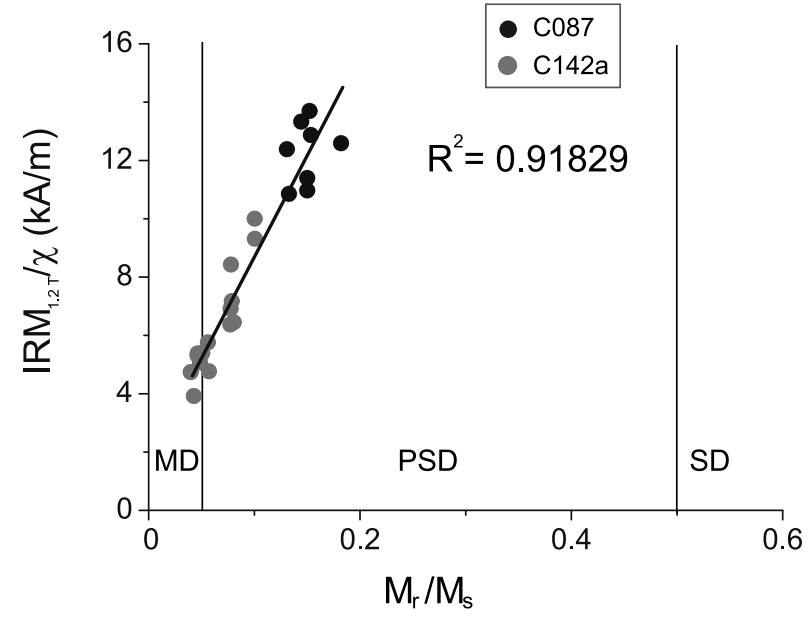

b)

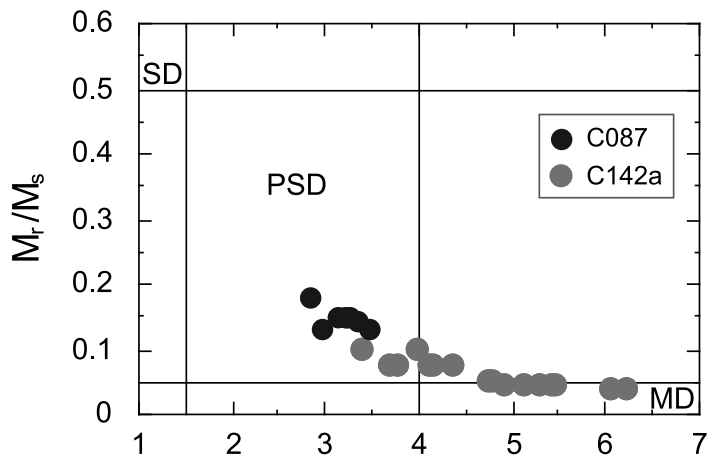

d)

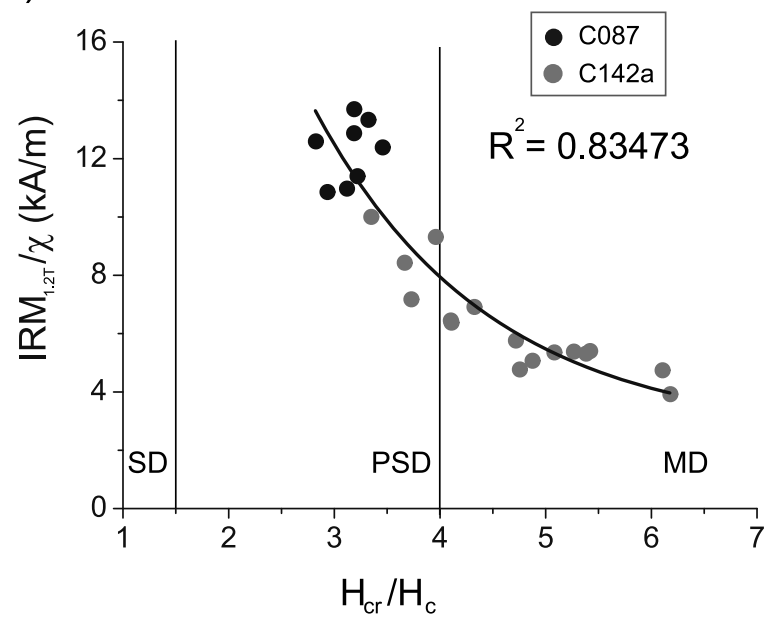

Figure 4. (a) Representative hysteresis loop for the studied Issyk-Kul sediments (after paramagnetic slope correction). Back-field demagnetization data (inset) indicate lack of saturation at $200 \mathrm{mT}$, and, hence, a contribution from a high-coercivity mineral. (b) Day diagram [Day et al., 1977] for samples from cores C087 and C142a (SD = single domain, $\mathrm{PSD}=$ pseudo-single domain, $\mathrm{MD}=$ multidomain data fields). (c, d) Correlations among hysteresis parameters $\left(\mathrm{M}_{\mathrm{r}} / \mathrm{M}_{\mathrm{s}}\right.$ and $\left.\mathrm{H}_{\mathrm{cr}} / \mathrm{H}_{\mathrm{c}}\right)$ and $\mathrm{IRM}_{1.2 \mathrm{~T}} / \chi$.

[e.g., Snowball, 1997; Sagnotti and Winkler, 1999; Roberts et al., 2011]. The stable remanence component has been interpreted as the characteristic remanent magnetization (ChRM). The maximum angular deviation (MAD) [Kirschvink, 1980] obtained for the ChRM directions is generally $<5^{\circ}$, with mean MAD values of $4.4^{\circ}$ and $2.4^{\circ}$ for cores C142a and C087, respectively (Table 1). These low MADs attest to the quality of the calculated ChRM directions [e.g., Stoner and St-Onge, 2007], especially for core C087. Mean median destructive fields (MDFs) for cores $\mathrm{C} 142 \mathrm{a}$ and $\mathrm{C} 087$ are $21 \mathrm{mT}$ and $35.5 \mathrm{mT}$, respectively. MDF values correlate with $\mathrm{IRM}_{1.2 \mathrm{~T}} / \chi$, so that lower MDFs correspond to lower $\mathrm{IRM}_{1.2} \mathrm{~T} / \chi$ values and, hence, to coarser magnetic grains (Figure 6).

[17] Relevant paleomagnetic and rock-magnetic data are plotted as a function of age after transforming the respective depth scales into age using the independent radiocarbon-based age models for each core (Figure 2) [Larrasoaña et al., 2011]. The mean inclination for core $\mathrm{C} 142 \mathrm{a}$ is $34.6^{\circ}$ (Figure 6a); inclinations range between $79.3^{\circ}$ (1946 AD) and $10.7^{\circ}$ (350 BC). Progressively decreasing inclination is observed in this core from $1800 \mathrm{AD}$ to $800 \mathrm{BC}$. Before this age, inclinations increase sharply and are relatively constant $\left(\sim 35^{\circ}\right)$. The inclination pattern from core C087 (Figure 6b) has important differences in the amplitude of the features observed. For core C087, inclination varies from $61.6^{\circ}(460 \mathrm{AD})$ to $33.2^{\circ}(3560 \mathrm{BC})$ around a mean of $50.1^{\circ}$.

[18] Cores C142a and C087 are azimuthally unoriented and thus no absolute declination values could be obtained. We plot relative declinations centered around the mean declination for each core 
a) IK-15 (Core C142a)

$\operatorname{Dec}=351.1^{\circ}, \operatorname{lnc}=41.5^{\circ}$ $\mathrm{MAD}=2.0^{\circ}, \mathrm{AF}$ range $=20-80 \mathrm{mT}$

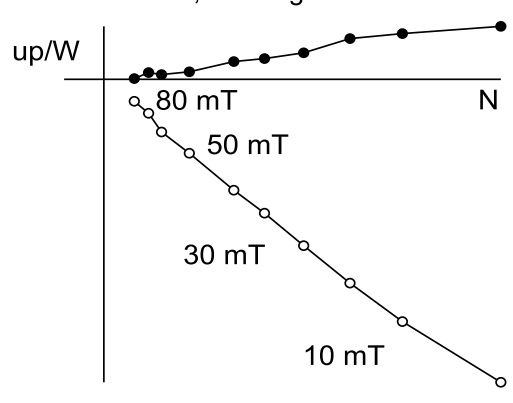

C) IK-26 (Core C142a)

$\mathrm{Dec}=339.1^{\circ}, \mathrm{Inc}=30.5^{\circ}$

$\mathrm{MAD}=1.7^{\circ}, \mathrm{AF}$ range $=20-80 \mathrm{mT}$
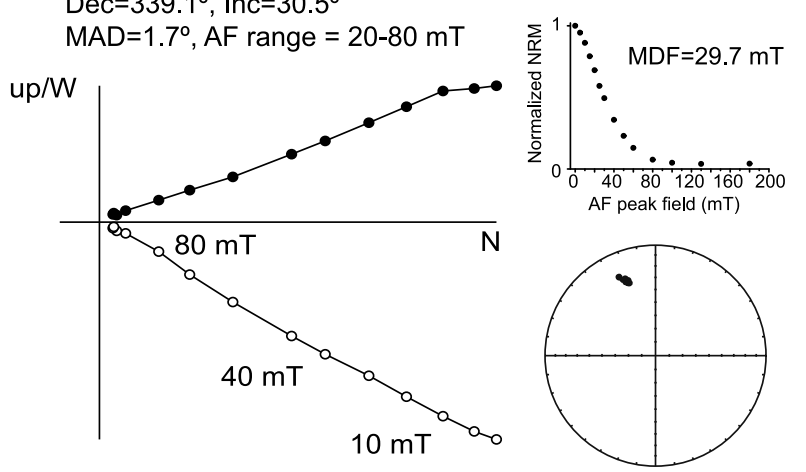

e) IK-55 (Core C142a)

$\mathrm{Dec}=18.0^{\circ}, \operatorname{Inc}=34.1^{\circ}$

$\mathrm{MAD}=3.4^{\circ}, \mathrm{AF}$ range $=20-80 \mathrm{mT}$

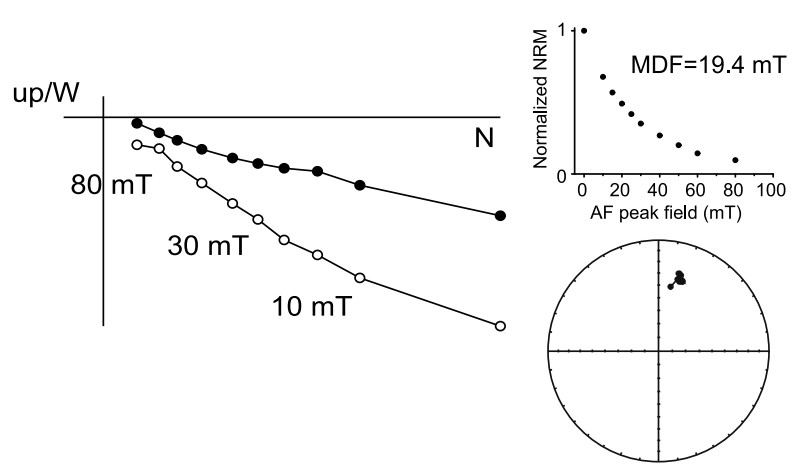

b) IKB-09 (Core C087)

$\mathrm{Dec}=27.3^{\circ}$, Inc $=55.4^{\circ}$

$\mathrm{MAD}=2.1^{\circ}, \mathrm{AF}$ range $=20-80 \mathrm{mT}$

up/W

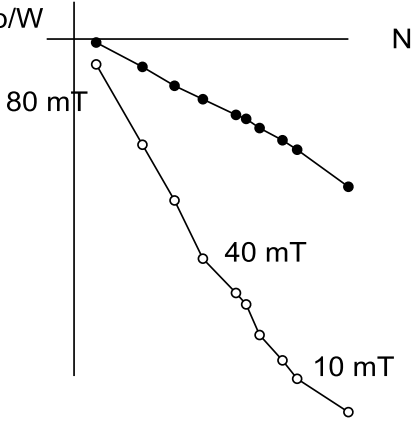

d) IKB-26 (Core C087)

$\mathrm{Dec}=17.6^{\circ}, \mathrm{Inc}=49.7^{\circ}$

$\mathrm{MAD}=2.9^{\circ}, \mathrm{AF}$ range $=20-80 \mathrm{mT}$

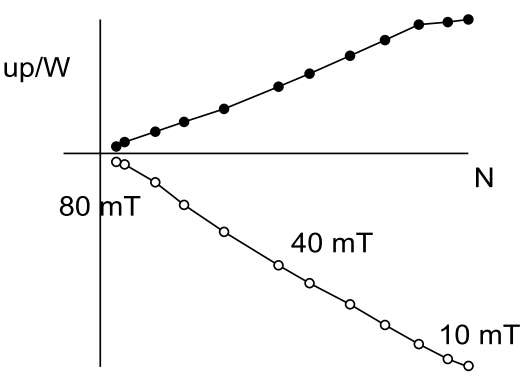

f) IKB-39 (Core C087)

$\mathrm{Dec}=27.3^{\circ}, \operatorname{lnc}=58.8^{\circ}$

$\mathrm{MAD}=1.8^{\circ}, \mathrm{AF}$ range $=20-80 \mathrm{mT}$

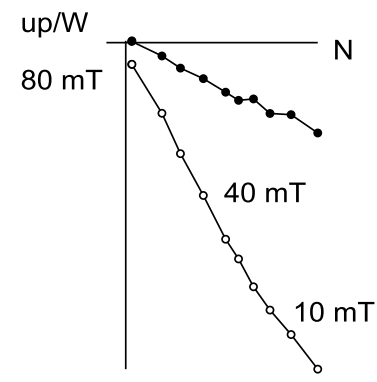

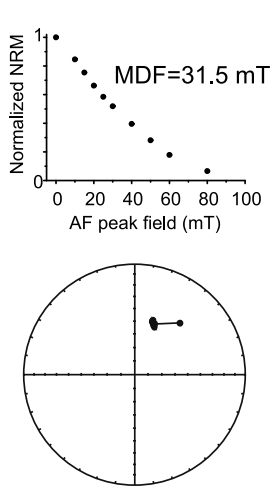
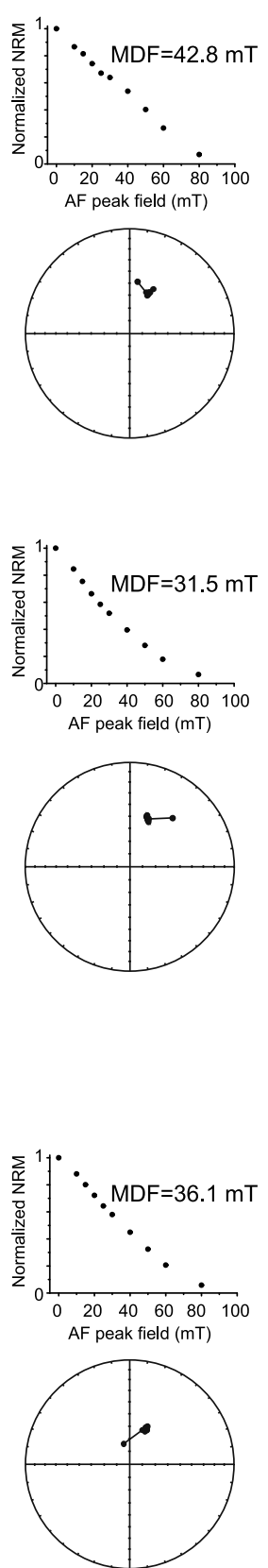

Figure 5. AF demagnetization behavior for representative samples from cores C142a and C087. In the Zijderveld [1967] diagrams, open and closed circles represent projections onto the vertical and horizontal planes, respectively. Corresponding stereographic projections and normalized NRM-intensity decay curves are also shown. Numbers indicate the peak applied AF and MDF determined for each sample.

(Figure 6). Relative declinations for core $\mathrm{C} 142 \mathrm{a}$ range between $-24.1^{\circ}$ (at $1721 \mathrm{AD}$ ) and $36.1^{\circ}$ $(1758 \mathrm{BC})$ and have a relatively flat trend between $1377 \mathrm{AD}$ and $275 \mathrm{BC}$ with a mean value of about $-9.5^{\circ}$ (Figure 6). Before this age, a progressive increase in declination is observed with a maximum at around $1758 \mathrm{BC}$. For core $\mathrm{C} 087$, relative declinations range between $-21.4^{\circ}(1579 \mathrm{AD})$ and $17.4^{\circ}$ (459 AD). The maximum declination reached at $459 \mathrm{AD}$ is followed by a progressive decrease down to $-10.3^{\circ}$ at $970 \mathrm{BC}$. Before this age, 
Table 1. Declination and Inclination Data for Cores C142a and C087 From Lake Issyk-Kul ${ }^{\mathrm{a}}$

\begin{tabular}{|c|c|c|c|c|c|}
\hline Sample & Depth $(\mathrm{cm})$ & Age (yr AD/BC) & Dec. (deg) & Inc. (deg) & MAD (deg) \\
\hline \multicolumn{6}{|c|}{ Core C142a $\left(42^{\circ} 34^{\prime} 31.2^{\prime \prime}, 77^{\circ} 20^{\prime} 03.0^{\prime \prime} E\right)$} \\
\hline IK01 & 1.1 & 1973.0 & 338.9 & 55.0 & 5.1 \\
\hline $\mathrm{IK} 02$ & 3.4 & 1916.5 & 348.6 & 79.3 & 2.8 \\
\hline IK03 & 5.8 & 1857.6 & 354.6 & 74.6 & 2.4 \\
\hline IK04 & 8.2 & 1798.6 & 348.4 & 78.5 & 5.8 \\
\hline IK05 & 10.6 & 1721.1 & 327.5 & 53.7 & 12.5 \\
\hline IK06 & 13.0 & 1634.3 & 5.8 & 54.1 & 9.2 \\
\hline IK07 & 15.4 & 1547.4 & 4.4 & 64.4 & 7.3 \\
\hline IK08 & 17.8 & 1460.6 & 357.7 & 44.6 & 3.7 \\
\hline IK09 & 20.2 & 1377.0 & 353.3 & 36.7 & 6.9 \\
\hline IK10 & 22.5 & 1314.5 & 348.8 & 27.6 & 9.2 \\
\hline IK11 & 25.0 & 1249.3 & 351.2 & 31.9 & 4.9 \\
\hline IK12 & 27.4 & 1184.2 & 345.9 & 28.6 & 8.0 \\
\hline IK13 & 29.8 & 1121.7 & 344.8 & 36.4 & 3.5 \\
\hline IK14 & 32.2 & 1057.8 & 344.9 & 42.1 & 4.8 \\
\hline IK15 & 34.6 & 994.0 & 351.1 & 41.5 & 2.0 \\
\hline IK16 & 37.0 & 930.1 & 350.3 & 47.5 & 4.5 \\
\hline IK17 & 39.4 & 866.3 & 350.6 & 41.0 & 1.9 \\
\hline IK18 & 41.7 & 837.9 & 346.7 & 37.0 & 1.6 \\
\hline IK19 & 44.1 & 822.1 & 347.0 & 32.0 & 3.1 \\
\hline IK20 & 46.5 & 806.4 & 348.0 & 37.7 & 1.5 \\
\hline IK21 & 48.9 & 790.7 & 342.6 & 33.8 & 1.5 \\
\hline IK22 & 51.3 & 775.0 & 343.1 & 40.8 & 1.8 \\
\hline IK23 & 53.7 & 759.6 & 340.6 & 32.9 & 1.3 \\
\hline IK24 & 56.0 & 744.2 & 341.0 & 36.6 & 1.0 \\
\hline IK25 & 58.4 & 728.5 & 341.8 & 35.2 & 1.1 \\
\hline IK26 & 60.8 & 692.9 & 339.1 & 30.5 & 1.7 \\
\hline IK27 & 63.2 & 617.5 & 341.0 & 33.9 & 1.7 \\
\hline IK28 & 65.6 & 542.2 & 341.0 & 33.4 & 2.3 \\
\hline IK29 & 68.0 & 466.8 & 336.2 & 25.2 & 1.6 \\
\hline IK30 & 70.4 & 393.0 & 336.5 & 23.9 & 1.6 \\
\hline IK31 & 72.7 & 319.2 & 338.8 & 24.9 & 2.0 \\
\hline IK32 & 75.1 & 243.9 & 337.7 & 18.7 & 2.2 \\
\hline IK33 & 77.5 & 170.1 & 337.0 & 22.4 & 1.6 \\
\hline IK34 & 79.8 & 97.9 & 336.5 & 26.2 & 2.2 \\
\hline IK35 & 82.1 & 24.1 & 337.6 & 27.4 & 1.8 \\
\hline IK36 & 84.5 & -51.3 & 338.2 & 29.1 & 2.1 \\
\hline IK37 & 86.9 & -126.7 & 328.9 & 24.9 & 3.7 \\
\hline IK38 & 89.3 & -200.5 & 334.7 & 26.0 & 4.9 \\
\hline IK39 & 91.6 & -274.2 & 329.8 & 15.0 & 4.4 \\
\hline IK40 & 94.0 & -349.6 & 332.9 & 10.7 & 3.3 \\
\hline IK41 & 96.4 & -423.4 & 336.1 & 13.3 & 2.7 \\
\hline IK42 & 98.7 & -497.2 & 340.5 & 16.7 & 2.9 \\
\hline IK43 & 101.2 & -562.1 & 342.7 & 18.1 & 2.8 \\
\hline IK44 & 103.6 & -612.3 & 349.9 & 25.1 & 5.8 \\
\hline IK45 & 105.9 & -660.5 & 346.9 & 16.6 & 6.6 \\
\hline IK46 & 108.2 & -709.7 & 353.1 & 11.0 & 5.0 \\
\hline IK47 & 110.6 & -759.9 & 5.8 & 18.4 & 8.4 \\
\hline IK48 & 113.0 & -809.1 & 348.3 & 39.3 & 6.9 \\
\hline IK49 & 115.3 & -858.3 & 351.2 & 37.0 & 9.3 \\
\hline IK50 & 117.7 & -908.5 & 3.1 & 34.1 & 5.4 \\
\hline IK51 & 120.1 & -957.7 & 16.8 & 35.2 & 5.1 \\
\hline IK52 & 122.4 & -1006.9 & 10.0 & 34.6 & 6.2 \\
\hline IK53 & 124.8 & -1057.1 & 13.2 & 30.2 & 7.7 \\
\hline IK54 & 127.2 & -1106.3 & 14.2 & 32.9 & 6.0 \\
\hline IK55 & 129.6 & -1156.6 & 18.0 & 34.1 & 3.4 \\
\hline IK56 & 132.0 & -1239.3 & 13.2 & 34.1 & 2.8 \\
\hline IK57 & 134.4 & -1325.4 & 21.2 & 32.9 & 2.5 \\
\hline IK58 & 136.7 & -1411.5 & 17.0 & 44.9 & 6.4 \\
\hline IK59 & 139.1 & -1497.7 & 26.1 & 34.3 & 6.3 \\
\hline IK60 & 141.4 & -1583.8 & 17.4 & 41.6 & 4.8 \\
\hline
\end{tabular}


Table 1. (continued)

\begin{tabular}{|c|c|c|c|c|c|}
\hline Sample & Depth $(\mathrm{cm})$ & Age (yr AD/BC) & Dec. (deg) & Inc. (deg) & MAD (deg) \\
\hline IK61 & 143.8 & -1671.7 & 18.5 & 30.6 & 7.4 \\
\hline IK62 & 146.2 & -1757.9 & 27.7 & 33.0 & 11.6 \\
\hline IK63 & 148.5 & -1849.5 & 18.0 & 34.7 & 5.7 \\
\hline \multicolumn{6}{|c|}{ Core C087 (42 $\left.34^{\prime} 5.22^{\prime \prime}, 77^{\circ} 20^{\prime} 10.44^{\prime \prime} E\right)$} \\
\hline IKB03 & 5.9 & 1683.0 & 22.26 & 57.8 & 2.3 \\
\hline IKB04 & 8.2 & 1579.0 & 5.80 & 58.0 & 3.4 \\
\hline IKB05 & 10.7 & 1465.9 & 25.45 & 53.2 & 2.4 \\
\hline IKB06 & 13.1 & 1357.3 & 37.29 & 54.8 & 1.6 \\
\hline IKB07 & 15.6 & 1244.2 & 32.45 & 54.1 & 1.4 \\
\hline IKB08 & 18.1 & 1131.0 & 15.48 & 56.3 & 2.0 \\
\hline IKB09 & 20.5 & 1022.5 & 27.28 & 55.4 & 2.1 \\
\hline IKB10 & 22.9 & 913.9 & 33.72 & 61.2 & 2.0 \\
\hline IKB11 & 25.3 & 805.3 & 38.21 & 57.9 & 1.4 \\
\hline IKB12 & 27.7 & 696.7 & 38.66 & 55.8 & 1.9 \\
\hline IKB13 & 30.1 & 588.1 & 38.53 & 57.1 & 1.4 \\
\hline IKB14 & 32.4 & 459.0 & 44.59 & 61.6 & 2.7 \\
\hline IKB15 & 35.0 & 307.2 & 37.34 & 50.3 & 2.8 \\
\hline IKB16 & 37.3 & 172.9 & 32.35 & 49.2 & 2.9 \\
\hline IKB17 & 39.7 & 32.7 & 37.84 & 47.4 & 3.2 \\
\hline IKB18 & 42.2 & -113.3 & 42.06 & 48.7 & 3.4 \\
\hline IKB19 & 44.7 & -259.3 & 43.29 & 48.7 & 2.5 \\
\hline IKB20 & 47.1 & -399.4 & 39.38 & 45.4 & 2.7 \\
\hline IKB21 & 49.5 & -539.6 & 34.05 & 42.2 & 2.9 \\
\hline IKB22 & 51.9 & -679.8 & 34.70 & 40.1 & 1.8 \\
\hline IKB23 & 54.2 & -814.1 & 30.91 & 39.6 & 2.5 \\
\hline IKB24 & 56.7 & -917.4 & 22.92 & 37.5 & 3.2 \\
\hline IKB25 & 59.0 & -969.8 & 16.93 & 43.7 & 3.7 \\
\hline IKB26 & 61.5 & -1026.8 & 17.57 & 49.7 & 2.9 \\
\hline IKB27 & 63.9 & -1081.5 & 21.08 & 50.3 & 1.6 \\
\hline IKB28 & 66.3 & -1136.2 & 15.58 & 45.3 & 4.3 \\
\hline IKB29 & 68.7 & -1191.0 & 18.82 & 49.5 & 1.8 \\
\hline IKB30 & 71.1 & -1245.7 & 21.06 & 52.2 & 2.1 \\
\hline IKB31 & 73.6 & -1302.7 & 21.80 & 51.6 & 3.4 \\
\hline IKB32 & 76.0 & -1357.4 & 15.29 & 51.8 & 0.8 \\
\hline IKB33 & 78.4 & -1412.1 & 22.44 & 56.0 & 2.2 \\
\hline IKB34 & 80.9 & -1477.9 & 19.38 & 57.6 & 3.2 \\
\hline IKB35 & 83.3 & -1585.1 & 17.77 & 53.9 & 1.8 \\
\hline IKB36 & 85.7 & -1692.4 & 26.73 & 56.1 & 1.2 \\
\hline IKB37 & 88.2 & -1804.1 & 18.40 & 58.9 & 2.8 \\
\hline IKB38 & 90.7 & -1915.9 & 21.55 & 53.0 & 2.2 \\
\hline IKB39 & 93.2 & -2027.6 & 27.29 & 58.8 & 1.8 \\
\hline IKB40 & 95.5 & -2130.4 & 22.97 & 53.3 & 1.5 \\
\hline IKB41 & 98.0 & -2242.1 & 22.98 & 46.4 & 2.0 \\
\hline IKB42 & 100.9 & -2371.8 & 30.24 & 54.5 & 3.6 \\
\hline IKB43 & 102.7 & -2452.2 & 26.51 & 48.0 & 1.4 \\
\hline IKB44 & 105.2 & -2563.9 & 26.74 & 48.1 & 1.5 \\
\hline IKB45 & 107.6 & -2671.2 & 23.48 & 49.5 & 3.1 \\
\hline IKB46 & 110.1 & -2782.9 & 26.16 & 49.8 & 1.4 \\
\hline IKB47 & 112.6 & -2894.7 & 32.79 & 47.9 & 2.5 \\
\hline IKB48 & 115.0 & -3001.9 & 25.30 & 43.1 & 2.0 \\
\hline IKB49 & 117.4 & -3109.2 & 34.06 & 44.5 & 2.8 \\
\hline IKB50 & 119.9 & -3220.9 & 22.53 & 45.3 & 3.4 \\
\hline IKB51 & 122.4 & -3332.7 & 30.17 & 43.2 & 2.4 \\
\hline IKB52 & 124.7 & -3435.5 & 29.65 & 38.6 & 2.4 \\
\hline IKB53 & 127.4 & -3556.1 & 26.04 & 33.2 & 4.3 \\
\hline IKB54 & 130.1 & -3676.8 & 18.63 & 38.3 & 3.0 \\
\hline
\end{tabular}

${ }^{a}$ Depths and the corresponding age obtained from the radiocarbon-based age models available for these cores (see Larrasoaña et al. [2011] for further details) are indicated for each sample. The maximum angular deviation (MAD) [Kirschvink, 1980] obtained for the characteristic remanent magnetizations are also given. The cores were azimuthally unoriented and no absolute declinations could be obtained. Note that only data from core C087 are interpreted as reliable recorders of geomagnetic field changes in the studied area. 
a) Core C142a
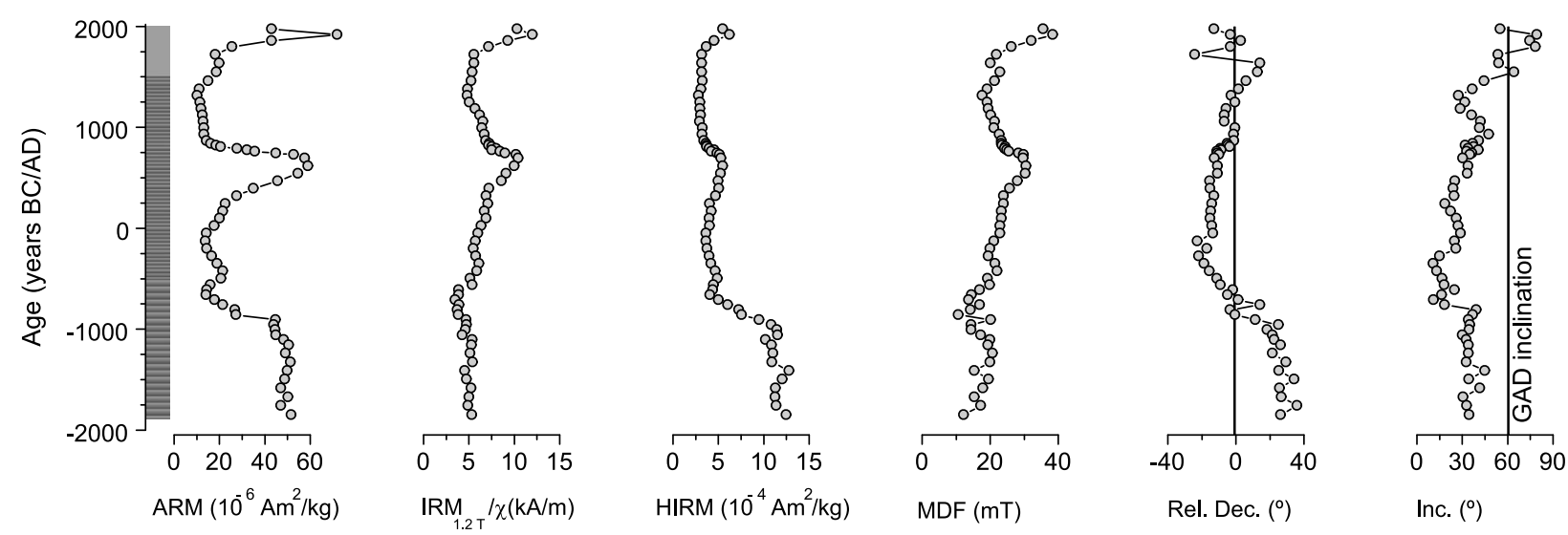

b) Core $\mathrm{C} 087$
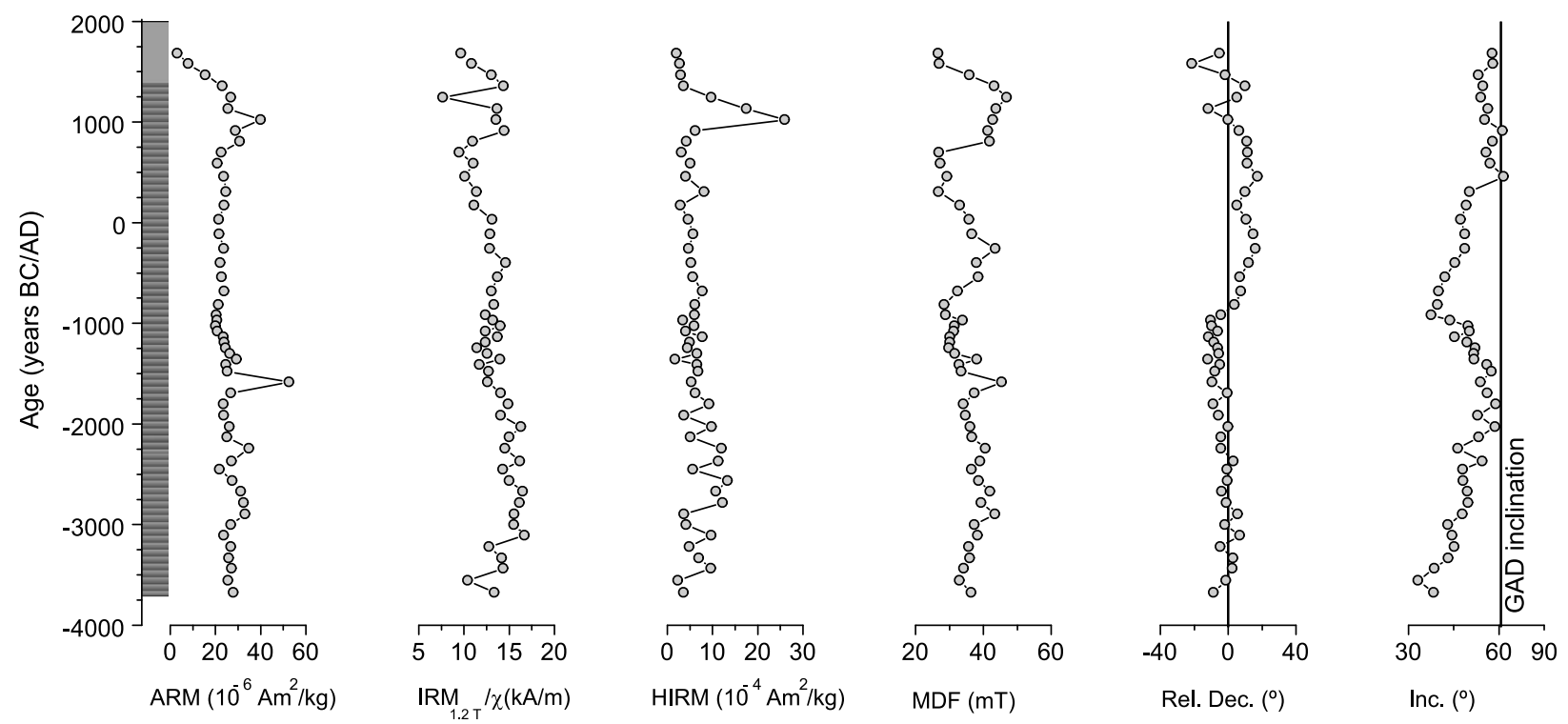

Figure 6. Temporal variations of ARM, IRM $\mathrm{I}_{1.2} \mathrm{~T} / \chi$, HIRM, median destructive field (MDF) and relative declination and absolute inclination of the characteristic remanent magnetization (ChRM) directions obtained for cores (a) $\mathrm{C} 142 \mathrm{a}$ and (b) C087. The inclination expected for a geocentric axial dipole (GAD) field at the site latitude is indicated by a black line. Each record is plotted using its own radiocarbon-based chronology [Larrasoaña et al., 2011 ].

relatively constant declinations of around $-3.5^{\circ}$ are observed.

\section{Discussion}

\subsection{PSV Data and Geomagnetic Field Models for Central Asia}

[19] Declination and inclination values for cores C087 and C142a are generally consistent between consecutive samples and reveal gradually varying directional changes (Figure 6). These changes appear to be unrelated to variations in lithology or rock magnetic properties, except for the uppermost part of core C142a (Figures 3 and 6). The mean paleomagnetic inclination for core $\mathrm{C} 087\left(50.1^{\circ}\right)$ is $11.0^{\circ}$ shallower than the expected inclination at the studied site $\left(61.0^{\circ}\right)$ for a geocentric axial dipole (GAD) field (Figure 6). This observed inclination flattening is typical of sediments where the ChRM is a detrital remanent magnetization (DRM) [e.g., Bressler and Elston, 1980; Tauxe, 2005; Tauxe et al., 2008], and is usually explained as a result of rolling of magnetic particles on the substrate during deposition and further compaction-induced inclination flattening that occurs after locking of the ChRM [Blow and Hamilton, 1978; Anson and Kodama, 1987; Tauxe et al., 2008]. In contrast, 
core C142a has a strikingly stronger average inclination flattening of $26.4^{\circ}$. Amplitudes of declination and inclination variations are about $30^{\circ}$ for core C087, which is compatible with expected values at the studied latitude as derived from available data and geomagnetic field models [Korte and Constable, 2005; Korte et al., 2005, 2009, and references therein]. In contrast, core $\mathrm{C} 142 \mathrm{a}$ has amplitudes of declination and inclination changes of about $60^{\circ}$ and $70^{\circ}$, respectively, which are much larger than expected for the studied location. Overall, these circumstances suggest that core $\mathrm{C} 087$, but not core $\mathrm{C} 142 \mathrm{a}$, could represent a reliable record of geomagnetic field variations in central Asia. Two main factors may account (perhaps in combination) for the inferred lower paleomagnetic reliability of core C142a. First, the magnetic carriers in these sediments fall mostly within the MD and coarse PSD grain size range (Figure 4). They are therefore less prone to be reliable recorders of stable paleomagnetic directions compared to core C087, which is characterized by finer PSD grain sizes (Figure 4). Second, the magnetic fabric of sediments from core C142a has a stronger tectonic imprint compared to core C087 sediments, probably because of their closer location to an active compressive, E-W oriented fault [Larrasoaña et al., 2011]. Such a tectonic overprint might have altered the spatial configuration of detrital magnetic particles in core C142a, thereby affecting the ChRM directions. Factors such as differential compaction after locking of the ChRM might also have affected the paleomagnetic recording fidelity of core C142a. Regardless of the specific cause(s), we consider that core C142 does not provide a reliable record of PSV at the studied site, so that only results from core C087 are hereafter considered.

[20] PSV data from core C087 from Lake Issyk-Kul are shown in Figure 7 along with PSV records from Lake Baikal, Lake Aslikul and the Aral Sea. A strikingly similar pattern can be observed between the inclination records from lakes Issyk-Kul and Baikal (Figure 7). Relative inclination minima at around $750-1000 \mathrm{BC}$ and $3500 \mathrm{BC}$, along with inclination maxima at around $750 \mathrm{AD}$ and $2000 \mathrm{BC}$, are observed for both records. The declination records from lakes Issyk-Kul and Baikal have some similarities such as the occurrence of relative declination maxima at around $1250 \mathrm{AD}, 250 \mathrm{BC}$, and $3250 \mathrm{BC}$, but also some significant discrepancies in the ages of declination minima (Figure 7). Given the large distance between lakes Issyk-Kul and Baikal (about $2300 \mathrm{~km}$ ) and their independent radiocarbon chronologies, we consider their records to be remarkably consistent. The inclination record from Lake Aslikul has a similar structure to those of lakes Issyk-Kul and Baikal, although some features appear to be shifted to younger ages before $500 \mathrm{AD}$ (Figure 7). This is the case for the inclination maximum at around $1250 \mathrm{BC}$ and the minima at $250 \mathrm{BC}$ and $2500 \mathrm{BC}$ in Lake Aslikul, which occur at $2000 \mathrm{BC}, 750-1000 \mathrm{BC}$, and $3500 \mathrm{BC}$, respectively, in lakes Issyk-Kul and Baikal. A similar shift to younger ages seems to occur in the main features of the Aslikul declination record compared to lakes Issyk-Kul and Baikal (Figure 7), although such shifts are less clear because of the less marked similarities among the records. Overall, this suggests a 500-1000 year offset to younger ages inferred before $500 \mathrm{AD}$ for Lake Aslikul on the basis of inclination data. The Aral Sea record is too short to enable reliable comparison.

[21] The family of spherical harmonic geomagnetic models [Korte and Constable, 2005; Korte et al., 2009], which includes the SED3K.1 (based only on lacustrine and rapidly accumulated marine sediments), ARCH3K.1 (based only on archeological and lava flow material) and CALS7K.2 models (based on all sources of paleomagnetic data), appear to reproduce, albeit with some differences in amplitude and resolution, the PSV recorded in Lake Aslikul (Figure 7). In contrast, the models reproduce well the structure of the PSV records from lakes Issyk-Kul and Baikal, although there appears to be a significant temporal offset before $500 \mathrm{AD}$. The records appear to be shifted to older ages, with offsets ranging between 500 and 1000 years.

[22] There are three alternative explanations for the observed age offsets among the PSV records. The first is that the features identified in the lakes IssykKul and Baikal records constitute genuine nondipolar features that are captured later in the west in Lake Aslikul. This interpretation is ad hoc and is difficult to support on geomagnetic grounds. Age differences of 500-1000 years are too large to be explained solely by westward drift of higher-term geomagnetic field components [Snowball et al., 2007]. The second possibility is that the lakes Issyk-Kul and Baikal PSV records are based on problematic chronologies linked, for example, to an undetected and/or time variable reservoir effect that yields older radiocarbon ages for sediments older than $500 \mathrm{AD}$. Given the distance and the striking differences in size and water chemistry between lakes Issyk-Kul and Baikal, [Herdendorf, 1982; Savvaitova and Petr, 1992], and keeping in mind the similarity between their PSV records, we 

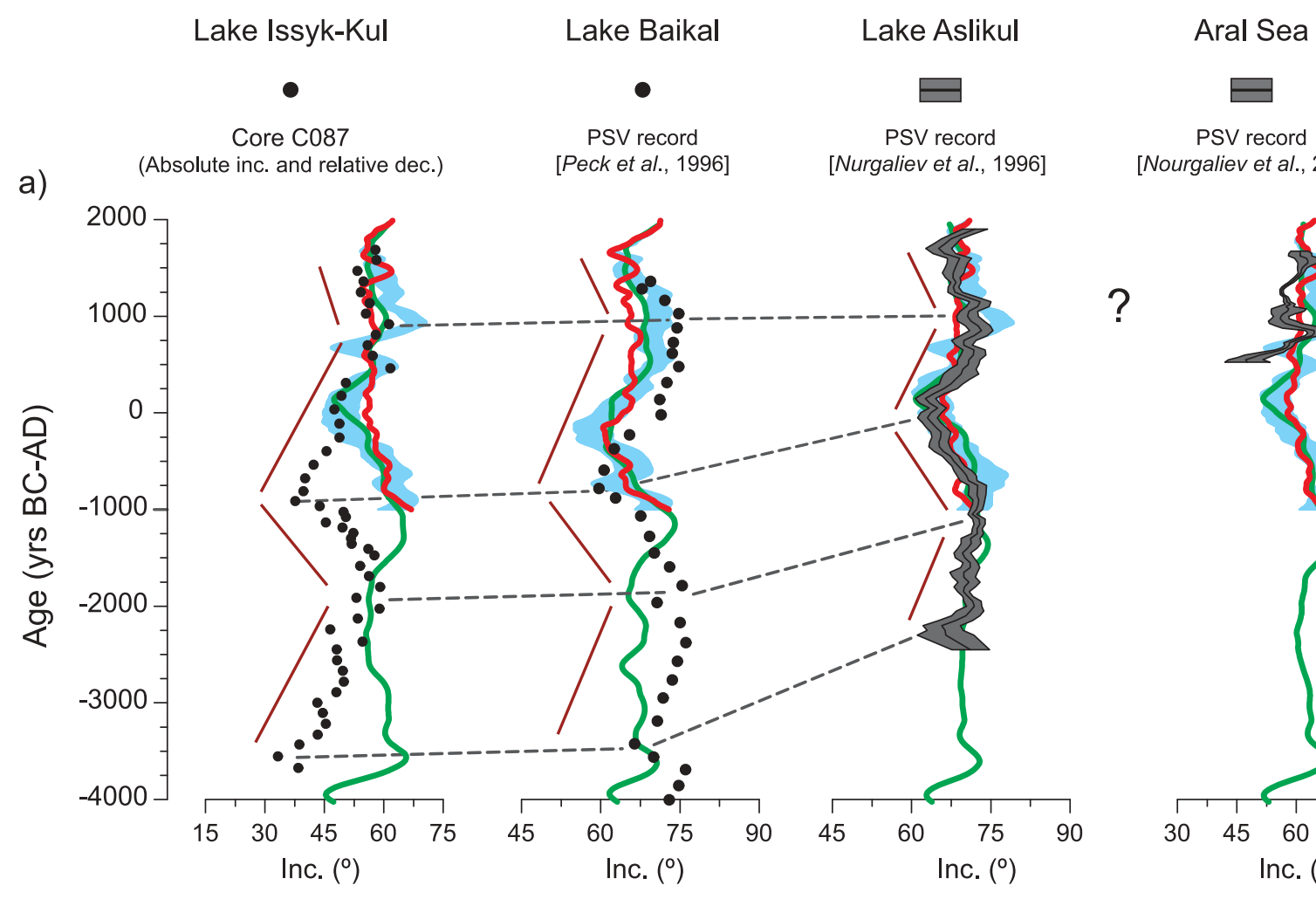

a)

PSV record
[Nourgaliev et al., 2003]
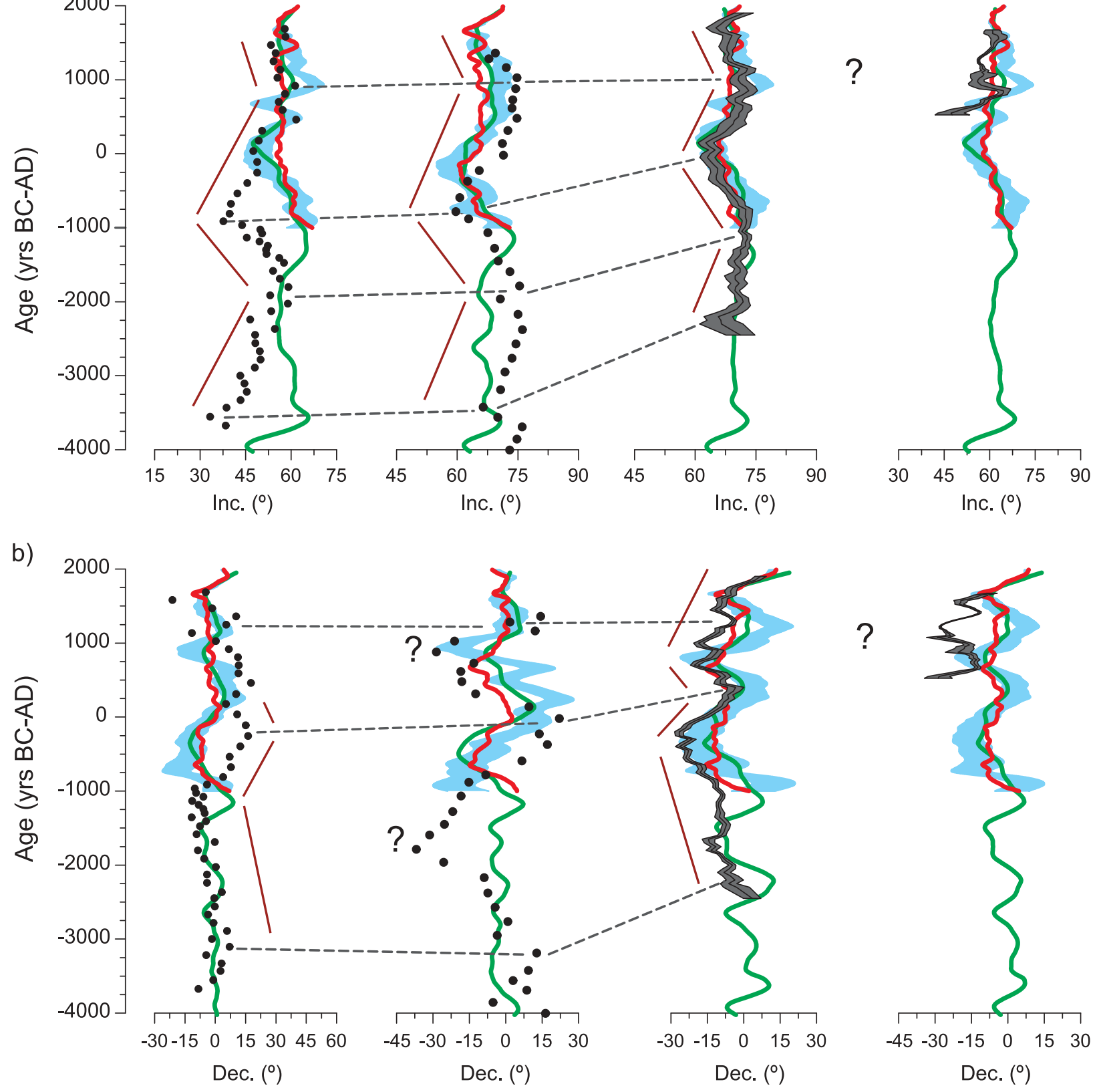

b)

Global geomagnetic field models:

ARCH3K.1 CALS7K.2

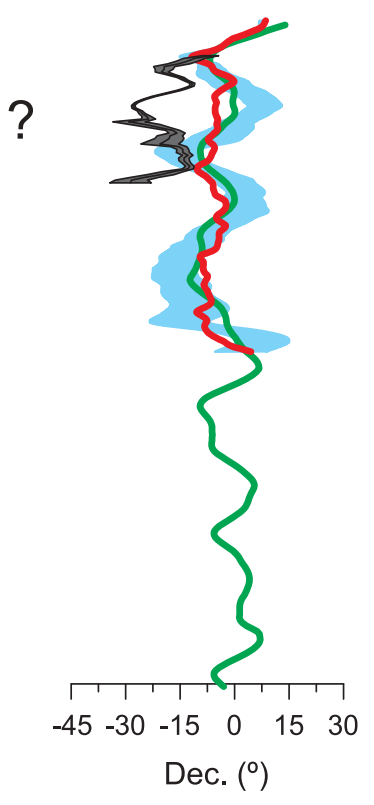

Figure 7. Comparison between the new PSV record obtained for Lake Issyk-Kul and published data from Lake Baikal [Peck et al., 1996], Lake Aslikul [Nurgaliev et al., 1996] and Aral Sea [Nourgaliev et al., 2003]. Declination and inclination values predicted for each location from geomagnetic field models [Korte and Constable, 2005; Korte et al., 2009] are also shown. Distinctive inclination and declination features are correlated and are labeled with dashed lines. 
consider this explanation unlikely. The third possibility is that the Lake Aslikul PSV record is shifted to younger ages due to either a delayed remanence acquisition [e.g., Sagnotti et al., 2005; Suganuma et al., 2011] or to an inaccurate chronological model. The age model for the Lake Aslikul record is not based on radiocarbon dating but on a correlation between a pollen-based paleoclimatic record and a radiocarbon-dated regional paleotemperature master curve [Klimanov and Khotinsky, 1988, pp. 45-51; Nurgaliev et al., 1996]. Keeping in mind the lack of a direct chronology for this record, we consider this explanation to be the most plausible. In this case, the discrepancies between the lakes Issyk-Kul and Baikal PSV records and the SED3K.1 and CALS7K.2 models might be explained by a strong temporal bias on the model results exerted by the Lake Aslikul record. However, this interpretation is difficult to reconcile with the ARCH3K.1 model (Figure 7), which has similar PSV trends to those of models SED3K.1 and CALS7K.2 and is independent of sedimentary PSV data. It should be noted, however, that the number of archeologic- and lava flow-derived PSV data decreases significantly for the first millennia BC in central Asia [Donadini et al., 2009], so there is the potential that future improvements in the number of source data for this period will improve the ARCH3K.1 model in the Lake Issyk-Kul region.

\subsection{Environmental Implications}

[23] The terrigenous fraction of the Holocene Lake Issyk-Kul sediments derives from the combined supply of riverine suspended material from the Jergueland and Tyup rivers and eolian dust sourced from the Taklamakan Desert [De Batist et al., 2002; Giralt et al., 2004]. Magnetite is ubiquitous in metamorphic, intrusive and volcanic rocks [Dunlop and Özdemir, 1997], such as those that dominate the catchment of Lake Issyk-Kul, and is also the main magnetic mineral in surface samples from the Taklamakan Desert [Torii et al., 2001]. Eolian dust from the Taklamakan Desert has been shown to contain hematite [Torii et al., 2001], which might also be common in the metamorphic, intrusive and volcanic rocks [Dunlop and Özdemir, 1997] of the Lake Issyk-Kul catchment. Hematite is therefore the most likely high-coercivity mineral in the studied sediments from Lake Issyk-Kul. Temporal variations in magnetite and hematite concentrations (as identified by variations in ARM and HIRM, respectively) in the two studied cores do not have a common pattern (Figure 6). The presence of both minerals in all potential terrigenous source sediments prevents reliable interpretation of magnetite and hematite abundances in terms of paleoenvironmental (riverine and dust) variations in the Lake Issyk-Kul area. Hysteresis and $\mathrm{IRM}_{1.2} \mathrm{~T} / \chi$ data indicate the presence of coarser-grained magnetite in core C142a sediments, which is consistent with sedimentological evidence for a higher sand content in this core and its location within a distributary channel of the deltaic system that drains into Lake Issyk-Kul from the NNW (Figure 1d). $\mathrm{IRM}_{1.2} \mathrm{~T} / \chi$ data do not have common variations in the two studied cores (Figure 6). More detailed rock magnetic studies are necessary to disentangle the environmental significance of magnetic mineralogic variations in the studied records.

\section{Conclusions}

[24] Stable paleomagnetic results from core C087 and an independent radiocarbon-based chronology indicate that mid to late Holocene sediments recovered from Lake Issyk-Kul provide a reliable record of PSV changes in central Asia. This is further supported by the overall similarity found between PSV records from lakes Issyk-Kul and Baikal, which are the only available Holocene central Asian PSV records with independent radiocarbon-based chronologies. Although similar in structure, significant temporal offsets before 500 AD exist between these two PSV records and those of Lake Aslikul and from global geomagnetic field models. We attribute the age offsets to the indirect age model on which the Lake Aslikul PSV record is based and to the strong bias that this record exerts on the global model results. Although additional well-dated PSV records are still needed to obtain a more robust understanding of regional PSV in central Asia and to improve geomagnetic field models, our new data represent a step in this direction. Our results also illustrate the potential of PSV records as a tool for dating sedimentary sequences, especially by matching inclination features, in a region that is key for unraveling teleconnections between high- and low-latitude climatic processes [Rohling et al., 2009; Yang et al., 2009]. Available bulk rock magnetic data have proved unsuccessful for disentangling past environmental changes in the Lake Issyk-Kul region, likely because magnetite and hematite, the two main magnetic minerals in the studied sediments, have a mixed (fluvial and eolian) terrigenous origin. 


\section{Acknowledgments}

[25] Financial support for this research was provided through a CSIC JAE-Doc post-doctoral research contract (MGP), the GRACCIE (Spanish Consolider-Ingenio CSD2007-00067), APELIK (EU ICA2-CT-2000-10003), CGL2008-02203/BTE, and PALEONAO (CGL2010-15767/BTE) research projects. We thank D. Nourgaliev for providing additional information concerning the Lake Aslikul and Aral Sea paleomagnetic records and four anonymous referees and the Associate Editor for their valuable, thorough and constructive comments that greatly improved this paper.

\section{References}

Ali, M., H. Oda, A. Hayashida, K. Takemura, and M. Torii (1999), Holocene palaeomagnetic secular variation at Lake Biwa, central Japan, Geophys. J. Int., 136, 218-228, doi:10.1046/j.1365-246X.1999.00718.x.

Anson, G. L., and K. P. Kodama (1987), Compaction-induced inclination shallowing of the post-depositional remanent magnetization in a synthetic sediment, Geophys. J. R. Astron. Soc., 88, 673-692, doi:10.1111/j.1365-246X.1987.tb01651.x.

Bard, E., and G. Delaygue (2008), Comment on "Are there connections between the Earth's magnetic field and climate?" by V. Courtillot et al., Earth Planet. Sci. Lett., 265, 302-307, doi:10.1016/j.eps1.2007.09.046.

Barletta, F., G. St-Onge, J. E. T. Channell, and A. Rochon (2010), Dating of Holocene western Canadian Arctic sediments by matching paleomagnetic secular variation to a geomagnetic field model, Quat. Sci. Rev., 29, 2315-2324, doi:10.1016/j.quascirev.2010.05.035.

Bloemendal, J., J. W. King, F. R. Hall, and S. J. Doh (1992), Rock magnetism of late Neogene and Pleistocene deep-sea sediments: Relationship to sediment source, diagenetic processes, and sediment lithology, J. Geophys. Res., 97, 4361-4375, doi:10.1029/91JB03068.

Blow, R. A., and N. Hamilton (1978), Effect of compaction on acquisition of a detrital remanent magnetization in finegrained sediments, Geophys. J. R. Astron. Soc., 52, 13-23, doi:10.1111/j.1365-246X.1978.tb04219.x.

Bressler, S. L., and D. P. Elston (1980), Declination and inclination errors in experimentally deposited specularite-bearing sand, Earth Planet. Sci. Lett., 48, 227-232, doi:10.1016/ 0012-821X(80)90184-3.

Courtillot, V., Y. Gallet, J. L. Le Mouël, F. Fluteau, and A. Genevey (2007), Are there connections between the Earth's magnetic field and climate?, Earth Planet. Sci. Lett., 253, 328-339, doi:10.1016/j.epsl.2006.10.032.

Day, R., M. Fuller, and V. A. Schmidt (1977), Hysteresis properties of titanomagnetites: Grain size and composition dependence, Phys. Earth Planet. Inter., 13, 260-267, doi:10.1016/ 0031-9201(77)90108-X.

De Batist, M., J. Klerkx, Y. Imbo, S. Giralt, V. Lignier, C. Beck, D. Delvaux, P. Vermeesch, I. Kalugin, and K. Abdrachmatov (2002), Bathymetry and sedimentary environments of a large, high-altitude, tectonic lake: Lake Issyk-Kul, Kyrgyz Republic (central Asia), in The Issyk-Kul Lake: Evaluation of Environmental State and Its Remediation, NATO ASI Ser., IV, vol. 13, edited by J. Klerkx and B. Imanackunov, pp. 101-124, Kluwer Acad., Dordrecht, Netherlands, doi:10.1007/978-94010-0491-6_9.
Donadini, F., M. Korte, and C. G. Constable (2009), Geomagnetic field for 0-3 ka: New data sets for global modeling, Geochem. Geophys. Geosyst., 10, Q06007, doi:10.1029/ 2008GC002295.

Dunlop, D. J. (2002), Theory and application of the Day plot $\left(\mathrm{M}_{\mathrm{rs}} / \mathrm{M}_{\mathrm{s}}\right.$ versus $\left.\mathrm{H}_{\mathrm{cr}} / \mathrm{H}_{\mathrm{c}}\right)$ : 2. Application to data for rocks, sediments and soils, J. Geophys. Res., 107(B3), 2057, doi:10.1029/2001JB000487.

Dunlop, D. J., and Ö. Özdemir (1997), Rock Magnetism, Fundamentals and Frontiers, Cambridge Univ. Press, Cambridge, U. K., doi:10.1017/CBO9780511612794.

Evans, M. E., and F. Heller (2003), Environmental Magnetism, Academic, San Diego, Calif.

Frank, U., and N. R. Nowaczyk (2008), Mineral magnetic properties of artificial samples systematically mixed from haematite and magnetite, Geophys. J. Int., 175, 449-461, doi:10.1111/j.1365-246X.2008.03821.x.

Frank, U., N. R. Nowaczyk, J. F. W. Negendank, and M. Melles (2002), A paleomagnetic record from Lake Lama, northern Central Siberia, Phys. Earth Planet. Inter., 133, 3-20, doi:10.1016/S0031-9201(02)00088-2.

Gallet, Y., A. Genevey, and F. Fluteau (2005), Does Earth's magnetic field secular variation control centennial climate change?, Earth Planet. Sci. Lett., 236, 339-347, doi:10.1016/ j.epsl.2005.04.045

Giralt, S., S. Riera, J. Klerkx, R. Julià, V. Lignier, C. Beck, M. De Batist, and I. Kalugin (2002), Recent paleoenvironmental evolution of Lake Issyk-Kul, in The Issyk-Kul Lake: Evaluation of Environmental State and Its Remediation, NATO ASI Ser., IV, vol. 13, edited by J. Klerkx and B. Imanackunov, pp. 125-145, Kluwer Acad., Dordrecht, Netherlands, doi:10.1007/978-94-010-0491-6_10.

Giralt, S., et al. (2004), 1000 year environmental history of Lake Issyk-Kul, in Dying and Dead Seas: Climatic Versus Anthropic Causes, NATO ASI Ser., IV, vol. 36, edited by J. C. J. Nihoul, P. O. Zavialov, and P. P. Micklin, pp. 253-285, Kluwer Acad., Dordrecht, Netherlands, doi:10.1007/978-94007-0967-6 10.

Gómez-Paccard, M., A. Chauvin, P. Lanos, G. McIntosh, M. L. Osete, G. Catanzariti, V. C. Ruiz-Martinez, and J. I. Nuñez (2006), First archaeomagnetic secular variation curve for the Iberian Peninsula: Comparison with other data from western Europe and with global geomagnetic field models, Geochem. Geophys. Geosyst., 7, Q12001, doi:10.1029/ 2006GC001476.

Gómez-Paccard, M., A. Chauvin, P. Lanos, and J. Thiriot (2008), New archeointensity data from Spain and the geomagnetic dipole moment in western Europe over the past 2000 years, J. Geophys. Res., 113, B09103, doi:10.1029/ 2008JB005582.

Herdendorf, C. E. (1982), Large lakes of the world, J. Great Lakes Res., 8, 379-412, doi:10.1016/S0380-1330(82)71982-3.

Irurzun, M. A., C. G. S. Gogorza, M. A. E. Chaparro, J. M. Lirio, H. Nuñez, J. F. Vilas, and A. M. Sinito (2006), Paleosecular variations recorded by Holocene-Pleistocene sediments from Lake El Trébol (Patagonia, Argentina), Phys. Earth Planet. Inter., 154, 1-17, doi:10.1016/j.pepi.2005. 06.012 .

Irurzun, M. A., C. G. S. Gogorza, A. M. Sinito, M. A. E. Chaparro, H. Nuñez, and J. M. Lirio (2008), Paleosecular variations $12-20 \mathrm{kyr}$ as recorded by sediments from Lake Moreno (southern Argentina), Stud. Geophys. Geod., 52, 157-172, doi:10.1007/s11200-008-0011-5. 
Kirschvink, J. L. (1980), The least-squares line and plane and the analysis of paleomagnetic data, Geophys. J. R. Astron. Soc., 62, 699-718, doi:10.1111/j.1365-246X.1980.tb02601.x.

Klimanov, V. A., and N. A. Khotinsky (Eds.) (1988), Paleoclimates of the Holocene of the European Part of USSR [in Russian], Inst. Geogr. Sci. Acad. USSR, Moscow.

Korte, M., and C. G. Constable (2005), Continuous geomagnetic field models for the past 7 millennia: 2. CALS7K, Geochem. Geophys. Geosyst., 6, Q02H16, doi:10.1029/ 2004GC000801.

Korte, M., A. Genevey, C. G. Constable, U. Frank, and E. Schnepp (2005), Continuous geomagnetic field models for the past 7 millennia: 1. A new global data compilation, Geochem. Geophys. Geosyst., 6, Q02H15, doi:10.1029/ 2004GC000800.

Korte, M., F. Donadini, and C. G. Constable (2009), Geomagnetic field for 0-3 ka: 2. A new series of time-varying global models, Geochem. Geophys. Geosyst., 10, Q06008, doi:10.1029/ $2008 \mathrm{GC} 002297$.

Kruiver, P. P., and H. F. Passier (2001), Coercivity analysis of magnetic phases in sapropel S1 related to variations in redox conditions, including an investigation of the $\mathrm{S}$ ratio, Geochem. Geophys. Geosyst., 2(12), 1063, doi:10.1029/ $2001 \mathrm{GC} 000181$.

Larrasoaña, J. C., A. P. Roberts, R. J. Musgrave, E. Gracia, E. Pinero, M. Vega, and F. Martinez-Ruiz (2007), Diagenetic formation of greigite and pyrrhotite in gas hydrate marine sedimentary systems, Earth Planet. Sci. Lett., 261, 350-366, doi:10.1016/j.eps1.2007.06.032.

Larrasoaña, J. C., M. Gómez-Paccard, S. Giralt, and A. P. Roberts (2011), Rapid locking of tectonic magnetic fabrics in weakly deformed mudrocks, Tectonophysics, 507, 16-25, doi:10.1016/j.tecto.2011.05.003.

Lisé-Pronovost, A., G. St-Onge, S. Brachfeld, F. Barletta, and D. Darby (2009), Paleomagnetic constraints on the Holocene stratigraphy of the Arctic Alaskan margin, Global Planet. Change, 68, 85-99, doi:10.1016/j.gloplacha.2009.03.015.

Muscheler, R., J. Beer, P. W. Kubik, and H. A. Synal (2005), Geomagnetic field intensity during the last 60,000 years based on ${ }^{10} \mathrm{Be}$ and ${ }^{36} \mathrm{Cl}$ from the Summit ice cores and ${ }^{14} \mathrm{C}$, Quat. Sci. Rev., 24, 1849-1860, doi:10.1016/j.quascirev. 2005.01.012.

Néel, L. (1955), Some theoretical aspects of rock-magnetism, Adv. Phys., 4, 191-243, doi:10.1080/00018735500101204.

Nourgaliev, D. K., F. Heller, A. S. Borisov, I. Hajdas, G. Bonani, P. G. Iassonov, and H. Oberhänsli (2003), Very high resolution paleosecular variation record for the last 1200 years from the Aral Sea, Geophys. Res. Lett., 30(17), 1914, doi:10.1029/2003GL018145.

Nurgaliev, D. K., A. S. Borisov, F. Heller, B. V. Burov, P. G. Jasonov, D. I. Khasanov, and S. Z. Ibragimov (1996), Geomagnetic secular variation through the last 3500 years as recorded by Lake Aslikul sediments from eastern Europe (Russia), Geophys. Res. Lett., 23, 375-378, doi:10.1029/ 96GL00258.

Pavón-Carrasco, F. J., M. L. Osete, J. M. Torta, and L. R. Gaya-Piqué (2009), A regional archeomagnetic model for Europe for the last 3000 years, SCHA.DIF.3K: Applications to archeomagnetic dating, Geochem. Geophys. Geosyst., 10, Q03013, doi:10.1029/2008GC002244.

Peck, J. A., J. W. King, S. M. Colman, and V. A. Kravchinsky (1996), An 84-kyr paleomagnetic record from the sediments of Lake Baikal, Siberia, J. Geophys. Res., 101, 11,365-11,385, doi:10.1029/96JB00328.
Peters, C., and M. J. Dekkers (2003), Selected room temperature magnetic parameters as a function of mineralogy, concentration and grain size, Phys. Chem. Earth, 28, 659-667, doi:10.1016/S1474-7065(03)00120-7.

Ricketts, N. R., T. C. Johnson, E. T. Brown, K. A. Rasmussen, and V. V. Romanovsky (2001), The Holocene paleolimnology of Lake Issyk-Kul, Kyrgyzstan: Trace element and stable isotope composition of ostracodes, Palaeogeogr. Palaeoclimatol. Palaeoecol., 176, 207-227, doi:10.1016/ S0031-0182(01)00339-X.

Roberts, A. P., L. Chang, C. J. Rowan, C.-S. Horng, and F. Florindo (2011), Magnetic properties of sedimentary greigite $\left(\mathrm{Fe}_{3} \mathrm{~S}_{4}\right)$ : An update, Rev. Geophys., 49, RG1002, doi:10.1029/2010RG000336.

Rohling, E. J., Q. S. Liu, A. P. Roberts, J. D. Stanford, S. O. Rasmussen, P. L. Langen, and M. Siddall (2009), Controls on the East Asian monsoon during the last glacial cycle, based on comparison between Hulu Cave and polar ice-core records, Quat. Sci. Rev., 28, 3291-3302, doi:10.1016/j. quascirev.2009.09.007.

Sagnotti, L., and A. Winkler (1999), Rock magnetism and palaeomagnetism of greigite-bearing mudstones in the Italian peninsula, Earth Planet. Sci. Lett., 165, 67-80, doi:10.1016/ S0012-821X(98)00248-9.

Sagnotti, L., F. Budillon, J. Dinarès-Turell, M. Iorio, and P. Macri (2005), Evidence for a variable paleomagnetic lock-in depth in the Holocene sequence from the Salerno Gulf (Italy): Implications for "high-resolution" paleomagnetic dating, Geochem. Geophys. Geosyst., 6, Q11013, doi:10.1029/2005GC001043.

Savvaitova, K., and T. Petr (1992), Lake Issyk-Kul, Kirgizia, Int. J. Salt Lake Res., 1, 21-46, doi:10.1007/BF02904361.

Snowball, I. F. (1997), The detection of single-domain greigite $\left(\mathrm{Fe}_{3} \mathrm{~S}_{4}\right)$ using rotational remanent magnetization (RRM) and the effective gyro field $\left(\mathrm{B}_{\mathrm{g}}\right)$ : Mineral magnetic and palaeomagnetic applications, Geophys. J. Int., 130, 704-716, doi:10.1111/j.1365-246X.1997.tb01865.x.

Snowball, I., and R. Muscheler (2007), Palaeomagnetic intensity data: An Achilles heel of solar activity reconstructions, Holocene, 17, 851-859, doi:10.1177/0959683607080531.

Snowball, I., L. Zillén, A. Ojala, T. Saarinen, and P. Sandgren (2007), FENNOSTACK and FENNORPRIS: Varve dated Holocene palaeomagnetic secular variation and relative palaeointensity stacks for Fennoscandia, Earth Planet. Sci. Lett., 255, 106-116, doi:10.1016/j.epsl.2006.12.009.

Stockhausen, H. (1998), Geomagnetic palaeosecular variation $(0-13,000 \mathrm{yr}$ BP $)$ as recorded in sediments from three maar lakes from the West Eifel (Germany), Geophys. J. Int., 135, 898-910, doi:10.1046/j.1365-246X.1998.00664.x.

Stoner, J. S., and G. St-Onge (2007), Magnetic stratigraphy in paleoceanography: Reversals, excursions, paleointensity, and secular variation, in Proxies in Late Cenozoic Paleoceanography, Dev. in Mar. Geol., vol. 1, edited by C. HillaireMarcel and A. deVernal, pp. 99-138, Elsevier, Amsterdam, doi:10.1016/S1572-5480(07)01008-1.

Suganuma, Y., J. Okuno, D. Heslop, A. P. Roberts, T. Yamazaki, and Y. Yokoyama (2011), Post-depositional remanent magnetization lock-in for marine sediments deduced from ${ }^{10} \mathrm{Be}$ and paleomagnetic records through the Matuyama-Brunhes boundary, Earth Planet. Sci. Lett., 311, 39-52, doi:10.1016/j. eps1.2011.08.038.

Tauxe, L. (2005), Inclination flattening and the geocentric axial dipole hypothesis, Earth Planet. Sci. Lett., 233, 247-261, doi:10.1016/j.epsl.2005.01.027. 
Tauxe, L., K. P. Kodama, and D. V. Kent (2008), Testing corrections for paleomagnetic inclination error in sedimentary rocks: A comparative approach, Phys. Earth Planet. Inter., 169, 152-165, doi:10.1016/j.pepi.2008.05.006.

Thompson, R., and F. Oldfield (1986), Environmental Magnetism, Allen and Unwin, Boston, Mass.

Torii, M., T.-Q. Lee, K. Fukuma, T. Mishima, T. Yamazaki, H. Oda, and N. Ishikawa (2001), Mineral magnetic study of the Taklimakan desert sands and its relevance to the Chinese loess, Geophys. J. Int., 146, 416-424, doi:10.1046/j.0956540x.2001.01463.x.

Torizin, J., G. Jentzch, P. Malischewsky, J. Kley, N. Abakanov, and A. Kurskeev (2009), Rating of seismicity and reconstruction of the fault geometries in northern Tien Shan within the project "Seismic Hazard Assessment for Almaty," J. Geodyn., 48, 269-278, doi:10.1016/j.jog.2009.09.030.

Verosub, K. L., and A. P. Roberts (1995), Environmental magnetism: Past, present and future, J. Geophys. Res., 100, 2175-2192, doi:10.1029/94JB02713.

Vigliotti, L. (2006), Secular variation record of the Earth's magnetic field in Italy during the Holocene: Constraints for the construction of a master curve, Geophys. J. Int., 165, 414-429, doi:10.1111/j.1365-246X.2005.02785.x.

Wollin, G., D. B. Ericson, and W. B. F. Ryan (1978), Climatic changes, magnetic intensity variations and fluctuations of eccentricity of Earth's orbit during past 2,000,000 years and mechanism which may be responsible for relationship, Earth Planet. Sci. Lett., 41, 395-397, doi:10.1016/0012821X(78)90170-X.

Yang, B., J. Wang, A. Bräuning, Z. B. Dong, and J. Esper (2009), Late Holocene climatic and environmental changes in arid central Asia, Quat. Int., 194, 68-78., doi:10.1016/j. quaint.2007.11.020

Zabirov, R. D., and V. N. Korotaev (1978), Location and morphometry of the lake [in Russian], in Lake Issyk-Kul, pp. 12-20, Illim, Frunze, Tajikistan.

Zijderveld, J. D. A. (1967), Demagnetization of rocks: Analysis of results, in Methods in Palaeomagnetism, edited by D. W. Collinson et al., pp. 254-286, Elsevier, Amsterdam. 